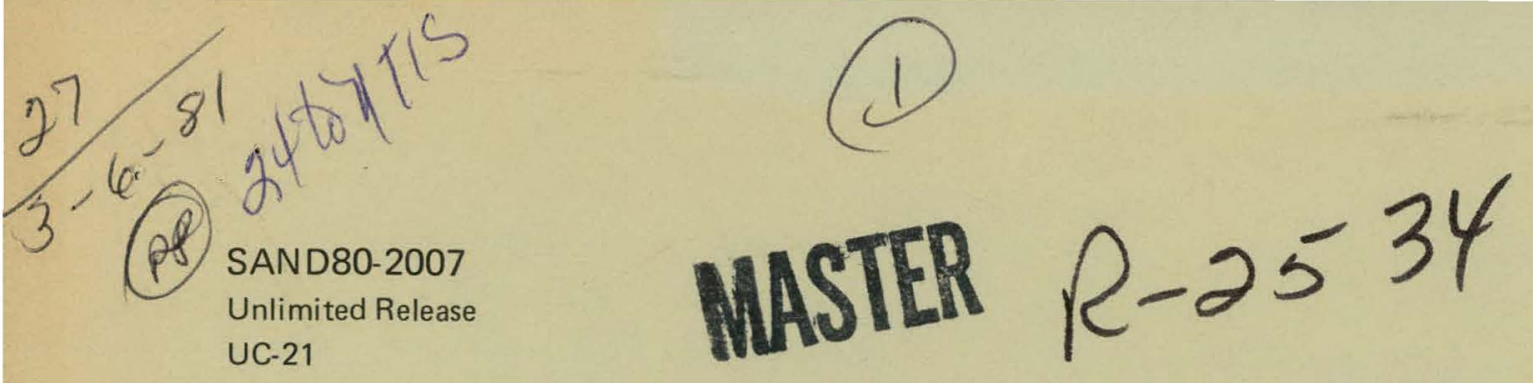

\title{
The T-3 Electron-Beam-Excited Laser System
}

Raymond A. Klein

Prepared by Sandia National Laboratories, Albuquerque, New Mexico 87185

and Livermore, California 94550 for the United States Department of Energy inder Contract DE-AC04-76DP0078:

Printed February 1981 


\section{DISCLAIMER}

This report was prepared as an account of work sponsored by an agency of the United States Government. Neither the United States Government nor any agency Thereof, nor any of their employees, makes any warranty, express or implied, or assumes any legal liability or responsibility for the accuracy, completeness, or usefulness of any information, apparatus, product, or process disclosed, or represents that its use would not infringe privately owned rights. Reference herein to any specific commercial product, process, or service by trade name, trademark, manufacturer, or otherwise does not necessarily constitute or imply its endorsement, recommendation, or favoring by the United States Government or any agency thereof. The views and opinions of authors expressed herein do not necessarily state or reflect those of the United States Government or any agency thereof. 


\section{DISCLAIMER}

Portions of this document may be illegible in electronic image products. Images are produced from the best available original document. 
Issued by Sandia Laboratories, operated for the United States Department of Energy by Sandia Corporation.

\section{NOTICE}

This report was prepared as an account of work sponsored by the United States Government. Neither the United States nor the Department of Energy, nor any of their employees, nor any of their contractors, subcontractors, or their employees, makes any warranty, express or implied, or assumes any legal liability or responsibility for the accuracy, completeness or usefulness of any information, apparatus, product or process disclosed, or represents that its use would not infringe privately owned rights. 


\section{PAGES 1 to 2 WERE INTENTIONALLY LEFT BLANK}




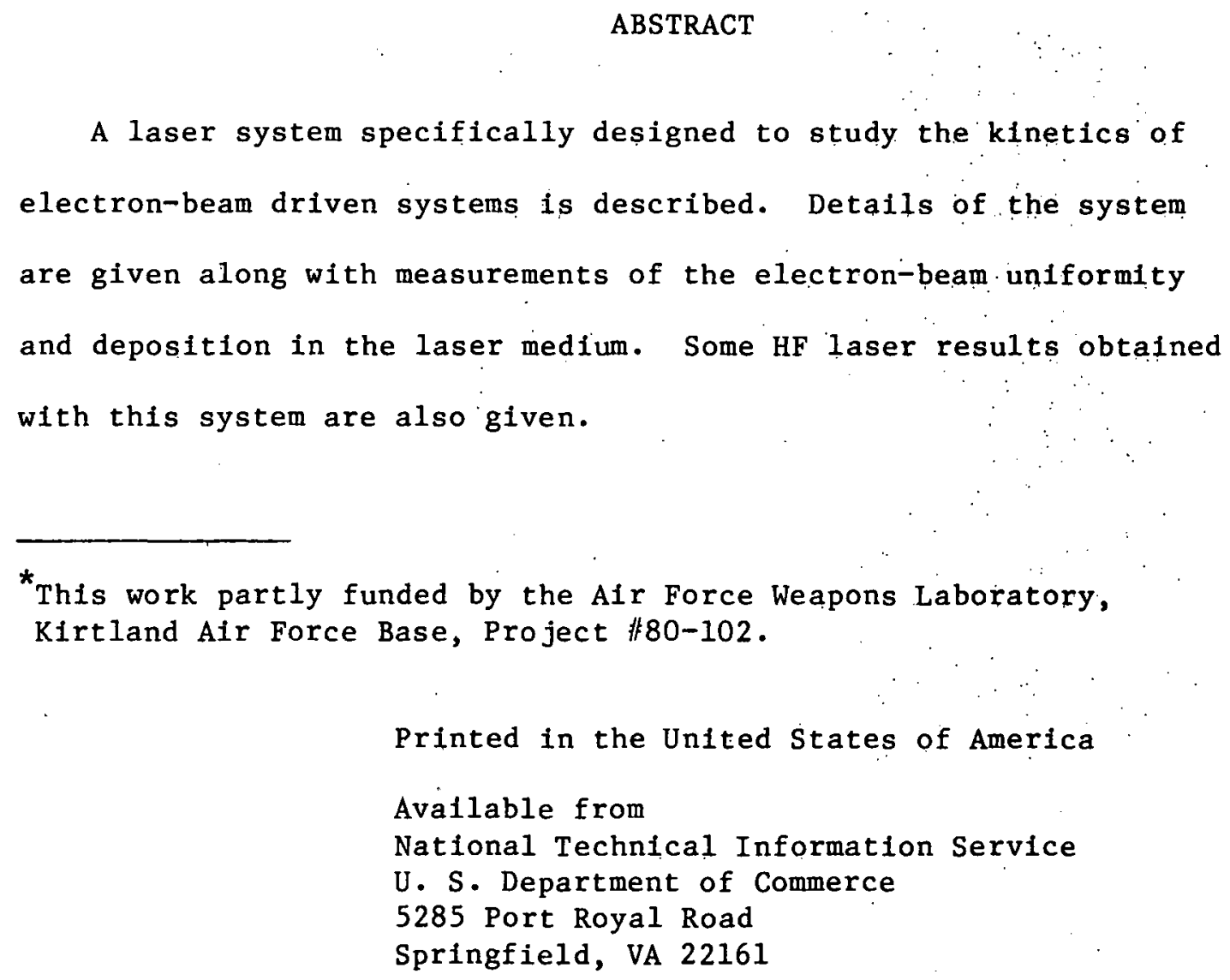

A laser system specifically designed to study the kinetics of electron-beam driven systems is described. Details of the system are given along with measurements of the electron-beam uniformity and deposition in the laser medium. Some HF laser results obtained with this system are also given.

* This work partly funded by the Air Force Weapons Laboratory, Kirtland Air Force Base, Project \#80-102. 
CONTENTS

$\underline{\text { Page }}$

I. Introduction $\ldots \ldots \ldots \ldots \ldots \ldots \ldots \ldots \ldots \ldots \ldots \ldots \ldots \ldots \ldots \ldots$

II. General Design of the System.................... 7

III. Electron-Beam Accelerator........................

IV. Design and Construction of the Laser Ce11............. 14

V. Design and Construction of Electron-Beam Calorimeter....... 15

VI. Measurements............................... $\ldots \ldots$

A. Accelerator Measurements,................... 17

B. Calorịeter Measurements.......................... 19

C. Pressure Rise Measurements...................... 22

D. Laser Measurements......................... 28

E. Other Measurements.......................... 30

VII. Conclusions................................ 30

FIGURE CAPTIONS

$\underline{\text { Page }}$

Fig. 1. Cutaway drawing of the $\mathrm{T}-3$ laser system.............. 8

F'ig. 2 . Photograph of experimental setup................... 10

Fig. 3. Block diagram of accelerator....................... 12

Fig. 4. Photograph of segmented calorimeter................ 16

Fig. 5. Diode energy as a function of diode voltages............ 18

Fig. 6. Electron-beam distribution near the anode.............20

Fig. 7. Electron-beam distribution in $\mathrm{SF}_{6}$ at a distance of

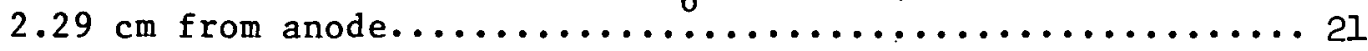

Fig. 8. Pressure rise as a function of nitrogen pressure

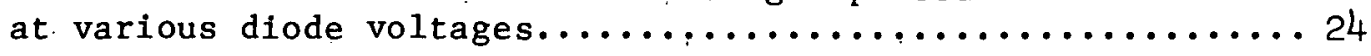


Fig. 9. Deposited energy in nitrogen as a function of

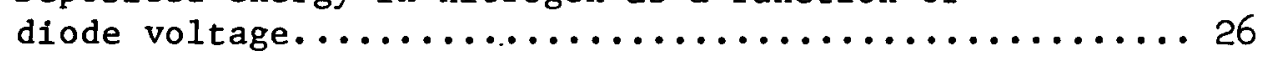

Fig. 10. Pressure rise as a function of pressure for

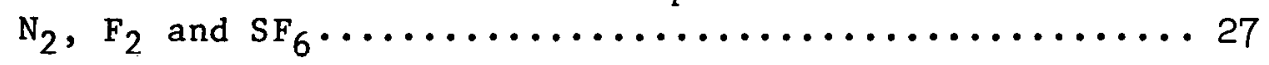

F1g. 11. Energy deposited as a function of density times length product for $\mathrm{N}_{2}, \mathrm{~F}_{2}$ and $\mathrm{SF}_{6} \ldots \ldots \ldots \ldots \ldots \ldots \ldots \ldots$

Fig. 12. Electron-beam current and laser intensity time histories................................. 31 


\section{Introduction}

The T-3 facilfty was developed so that detalled kinetic/optical studies could be performed on an electron-beam-1nitiated HF/DF chemical 1aser. The basic Idea was to develop a well characterized system so that detailed comparisons could be made with Sandia's laser code predictions. These comparisons would enable problem areas in the code to be more precisely identified. One of the major requirements of the system was that the electron deposition in the laser mixture be well characterized, both as to the uniformity and the amount of energy deposited. Another requirement was that the laser cell be so constructed that many diagnostics could be used during the same experiment. Some of the measurements planned for the $T-3$ device were to determine the $F$ atom concentration produced by the electron beam, to measure the $F_{2}$ disappearance and hence the overall reaction time in $\mathrm{H}_{2} / \mathrm{F}_{2}$ gas mixtures, to determine the $\mathrm{HF}$ bulld up caused by prereaction of the $\mathrm{H}_{2}$ and $\mathrm{F}_{2}$ and to determine small-signal gains on a number of laser lines.

This report will give detalls of the electron-beam system, including the design and construction of the laser cell. In addition, electron-beam deposition measurements and some preliminary laser measurements will be included.

\section{General Deslgn of the System}

A schematic representation of the T-3 system is shown in Fig. 1 . The electrons produced in the accelerator enter the laser cell transverse to the optical axis so that uniform excitation can be achieved. Hibachi structures which support the foils on both sides of the cell allow operation up to pressures of $5 \mathrm{~atm}$. A burst diaphragm is used to prevent the over pressure from the $\mathrm{H}_{2}+\mathrm{F}_{2}$ reaction from damaging the laser cell. The laser 


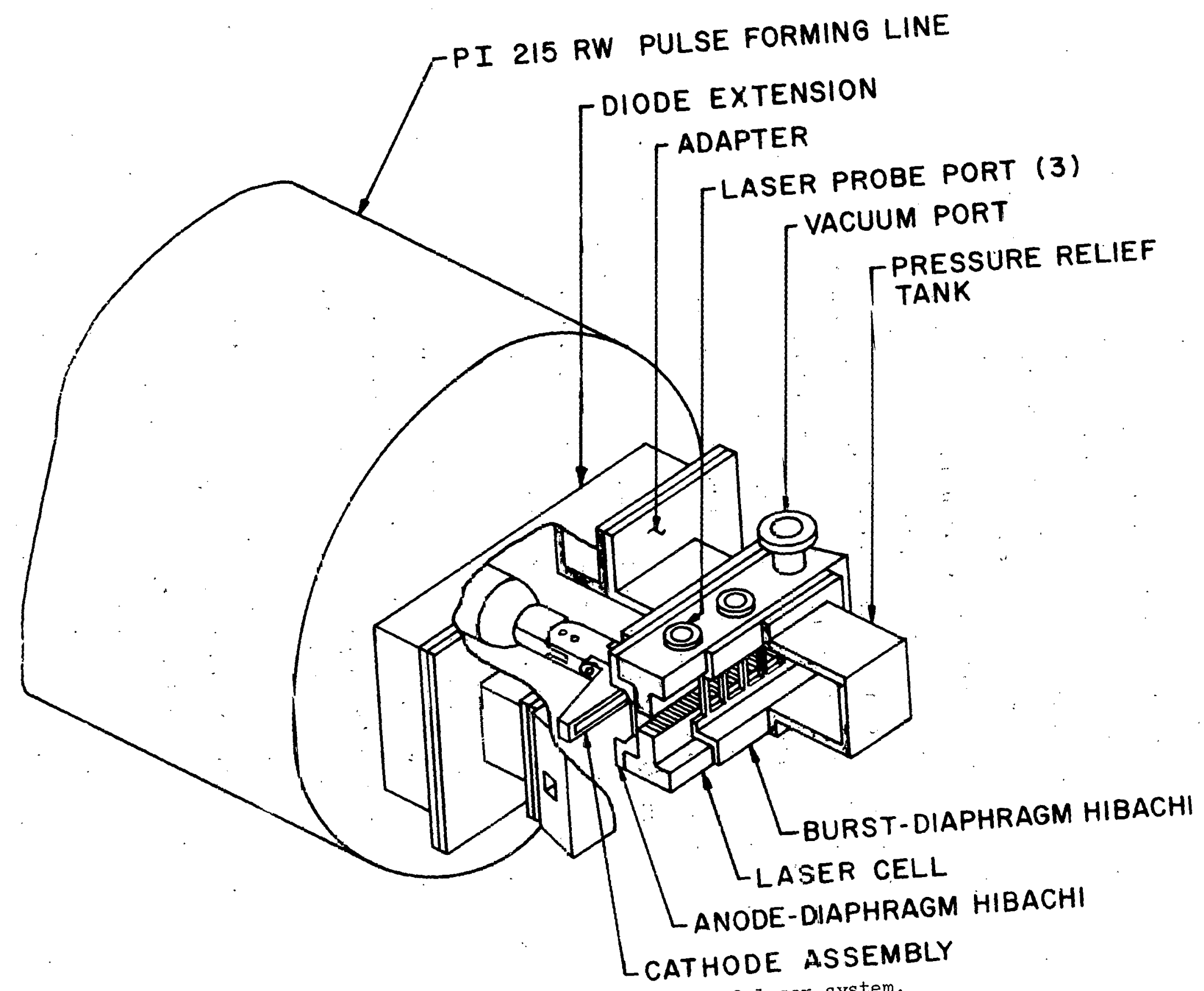

7. 1. Cutaway draving of the T-3 laser system. 
cell is also equipped with three vertical transverse laser probe ports so that optical measui ments can be made transverse to the optical axis.

The electron-beam accelerator ${ }^{1}$ has a pulse width of $50 \mathrm{nsec}$ and operates at voltages up to $520 \mathrm{kV}$ with currents up to $40 \mathrm{kA}$. The machine was originally designed to be a $0.5 \mathrm{~J}$ pulse-per-second KrF laser. ${ }^{2}$ The original machine has been modified for single pulse operation for the T-3 laser system.

A gas handling and pumpout system, similar to one previously described, ${ }^{3}$ is used with this system. Its function is to evacuate the laser cell to a base vacuum of $10^{-5}$ Torr and then fill the cell to various pressures of $\mathrm{F}_{2}, \mathrm{O}_{2}, \mathrm{H}_{2}, \mathrm{SF}_{6}$, and $\mathrm{HF}$ gases. The gas handling system is remotely controlled so that personnel need not run the risk of exposure to the caustic, explosive gas mixtures.

A photograph of the system is shown in Fig. 2. The moveable cart in the foreground contains vacuum pumps and $\mathrm{F}_{2}$ traps. Optics mounted to an optical bench are used to steer the probe laser beam into the cell for optical absorption measurements. The entire room, which contains the electron-beam machine and laser cell, is enclosed with concrete blocks and a lead door for $x$ ray shielding.

III. Electron-Beam Accelerator

The accelerator is a Physics International machine, Model PI 215WR. As was previously mentioned, this device was originally developed and used extensively for a $0.5 \mathrm{~J}, 1 \mathrm{pps}, \mathrm{KrF}$ laser at Los Alamos Scientific Laboratories. Upon its return to Sandia, the machine was rebuilt and modified for operation with the T-3 system. The modifications included a new triggering circuit and a new diode design. Since the accelerator is a commercial device, only a brief description will be given of its 


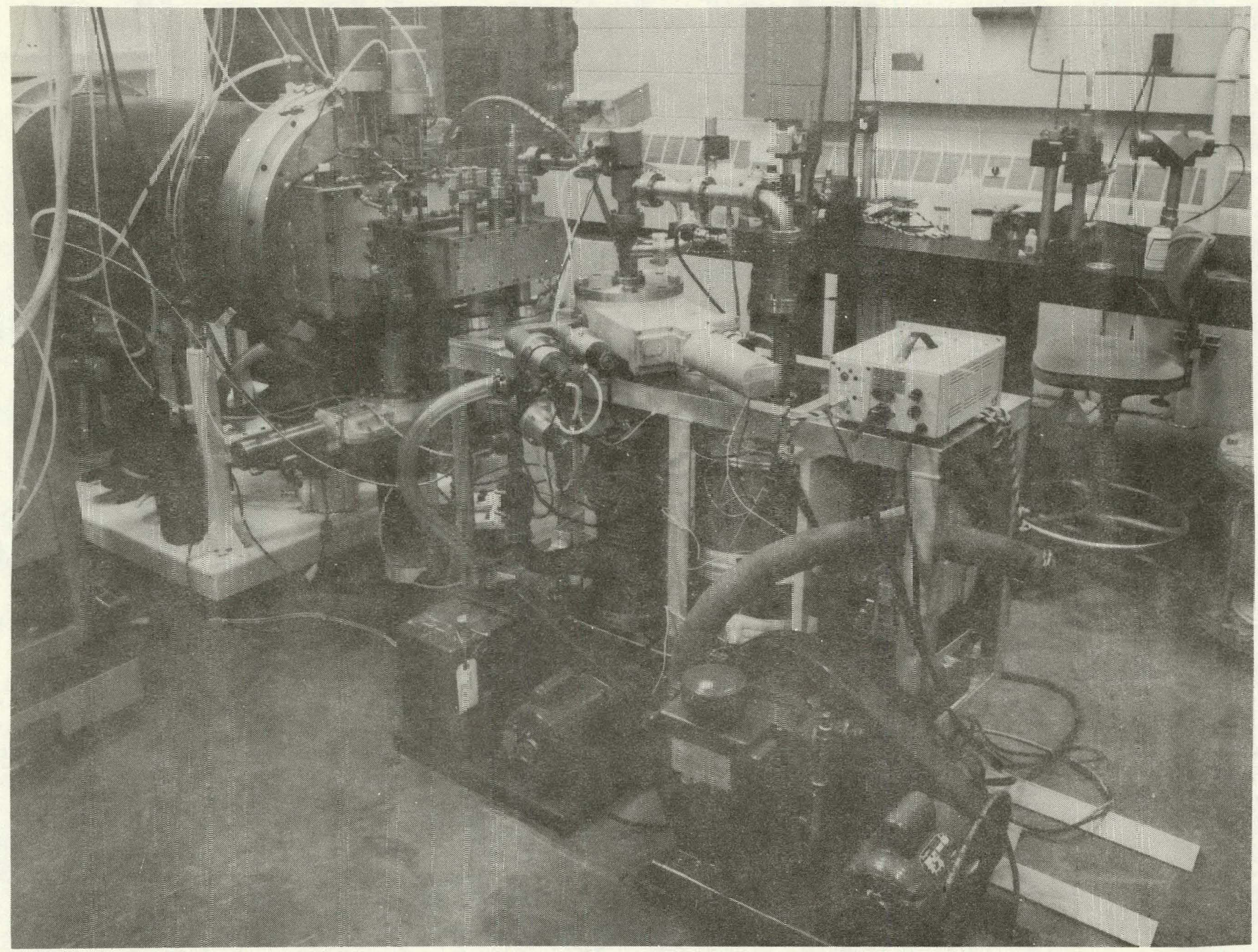

FiE. E. Phctograpi of experimental setup. 
operation; however, modifications to the machine will be described.

A block diagram of the accelerator is shown in Fig. 3. The Marx generator is immersed in oil to prevent electrical breakdown. The Marx is DC charged to a maximum of $38 \mathrm{kV} / \mathrm{stage.} \mathrm{There} \mathrm{are} 15$ stages whose series capacity is $3.2 \mathrm{nF}$. At a charge voltage of $38 \mathrm{kV}$, the Marx generator stores approximately $2 \mathrm{~kJ}$. The energy from the Marx charges a coaxial waterline, whose length determines the pulse width of the accelerator. The length of the line is $84 \mathrm{~cm}$, corresponding to an electron-beam pulse width of $50 \mathrm{nsec}$. The energy from the coaxial line is transferred to the diode by a self-triggering high-pressure gas switch. The pulse applied to the diode has an amplitude approximately half that of the switched voltage and a duration twice the transit time of the coaxial line. The operating $\mathrm{SF}_{6}$ gas pressure of the main switch varies from 60 psi for a $30 \mathrm{kV}$ Marx charge to 90 psi for a charge voltage of $38 \mathrm{kV}$. These pressures were determined by obtalning a self-breakdown curve (voltage versus $\mathrm{SF}_{6}$ pressure) after the machine was rebuilt.

The original trigger circult of the Marx was completely replaced. Before replacement, the trigger was a major source of problems with the machine. The new trigger oyotem for the T-3 oyotem incorporated a TC-70 pulse generator ${ }^{4}$ to trigger the first three stages of the Marx. This trigger system reduces the time jitter of the Marx generator to a few nsec.

The original diode had a $5 \mathrm{~cm} \times 30 \mathrm{~cm}$ cathode surface and was used to excite a volume of $6.35 \mathrm{~cm} \times 6.35 \mathrm{~cm} \times 30 \mathrm{~cm}$ long. The current density entering the laser chamber was approximately $110 \mathrm{~A} / \mathrm{cm}^{2}$. For chemical laser research, a current density of approximately $500 \mathrm{~A} / \mathrm{cm}^{2}$ was required; therefore, a new smaller area diode was designed. Also, it was desired to make the Impedance of the diode about $15 \mathrm{ohms}$ at $400 \mathrm{kV}$ to match the impedance of 


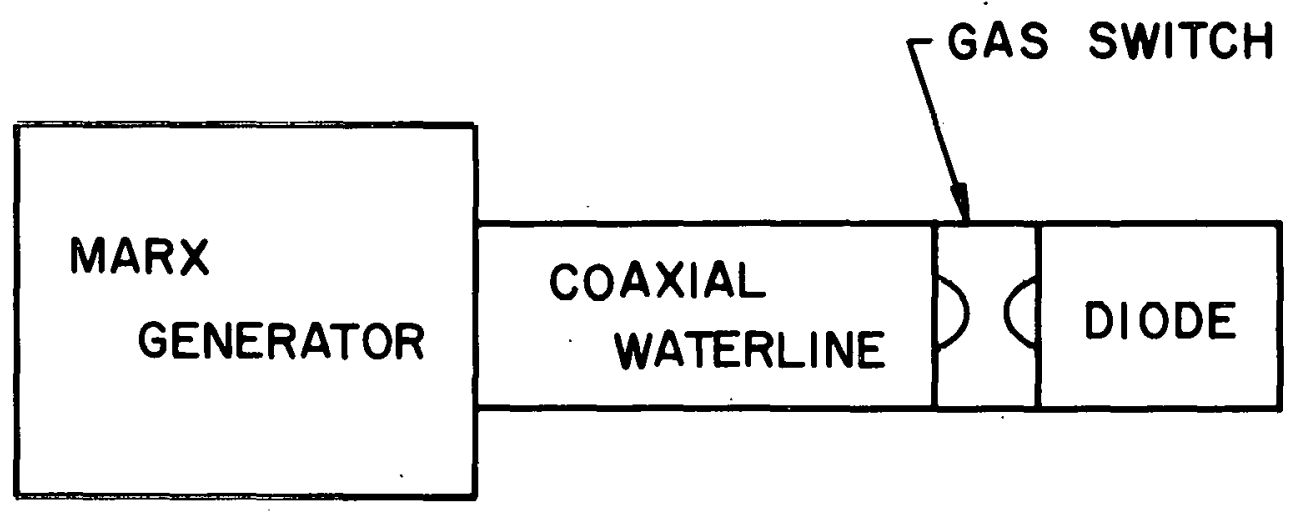

Fig. 3. Block diagram of accelerator. 
the coaxial line.

The impedance $c:$ the diode in ohms. is given by

$$
\mathrm{Z}=\frac{136 \pi}{\mathrm{V}_{\mathrm{d}^{\frac{1}{2}}}} \frac{\mathrm{d}^{2}}{\mathrm{~A}}
$$

where

$$
\begin{aligned}
\mathrm{d} & =\text { anode-cathode spacing } \\
\mathrm{V}_{\mathrm{d}} & =\text { diode voltage in megavolts } \\
\mathrm{A} & =\text { area of beam at the anode. }
\end{aligned}
$$

The cathode dimensions of $1.3 \mathrm{~cm} \times 24.3 \mathrm{~cm}$ gives the required current density. The cathode emitter consists of five "saw blades," the teeth of which provide multiple emitting surfaces. The total area of the beam at the anode was originally designed to be approximately $70 \mathrm{~cm}^{2}(2.5 \mathrm{~cm} \times 27.3 \mathrm{~cm})$. The anode-cathode spacing was then calculated to be $1.25 \mathrm{~cm}$. Measurements of the electron-beam uniformity were made at the anode by exposing bleachable cinemoid $\mathrm{film} \mathrm{m}^{5}$ to the electron beam. Anode-cathode gap spacings of $1.02 \mathrm{~cm}$ and $1.52 \mathrm{~cm}$ were used at various Marx charge voltages. The $1.52 \mathrm{~cm}$ spacing appeared to give the most uniform emission and, therefore, was used for the rest of the study. The charge voltage, diode voltage, diode current, measured impedance and calculated impedance are given in the following table.

Marx Charge

Voltage $(\mathrm{kV})$

30

34

36

38

$$
\underline{V_{d}(k V)} \quad \underline{I_{d}(k A)}
$$

28

34

38

40
$\underline{Z \text { Measured }(\Omega)}$

13.9

12.8

12.5

13.0
$\underline{Z \text { Calculated }(\Omega)}$

23.1

21.9

21.0

20.1 
As can be seen from the latter two columns of the table, there is a very large discrepancy between measured and.calculated impedance. The disagreement could be due to the fact that the area of the beam at the anode is larger than $70 \mathrm{~cm}^{2}$ If the area were $\approx 110 \mathrm{~cm}^{2}$, then the measured and calculated impedance would be in fair agreement. A larger area would also explain the large discrepancy between the diode energy and the energy measured by. the calorimeter. These discrepancies will be addressed in a later section.

IV. Design and Construction of the Laser Cell

A laser cell was needed that had the smallest unexcited volume as possible. Th1s was accomplished by constructing the laser cavity with a square cross section and using the anode foll and a burst dlaphragm to make up two of the cavity sides. This is shown in Fig. 1. The only unexcited volume in the laser cell is that associated with the vacuum and probe ports and a small dead volume adjacent to each window. The total cavity volume is $0.531 \ell$, of which $0.234 \ell$ is excited by the electron heam. A complete nop of laswi lavily drawings is located in the appendix at the end of this report.

There are three sets of viewing ports vertically through the cell with sapphire windows. For some experiments a cW HF probe laser is passed through these ports and the laser cavity. One port has bean modified for the insertiui of a pressure gauge. There are also small pressure probe tubes that allow pressure measurements at the anode.

Provisions were made inside the cell to install partitions that isolate a volume of $16.38 \mathrm{~cm}^{3}\left(1 \mathrm{In}^{3}\right)$, located in the center of the cell. This feature allows experiments to be performed on an small, known volume.

As shuwn in Dwg. 4, unwanted light reflection inside the laser cavity has been suppressed by machining small v-grooves perpendicular to the optical axis on all inside surfaces, except the vacuum and probe holes. In addition, the 
output windows are constructed of $0.64 \mathrm{~cm}$ thick sapphire and are inclined $20^{\circ}$ to the laser ax so as to prevent reflections into active laser volume and thereby reducing the possibility of parasitic laser modes.

The hibachi shown in Fig. 1 and in Dwg. 3 is used to support the anode foil against the overpressure resulting from $\mathrm{F}_{2}, \mathrm{O}_{2}$, and $\mathrm{H}_{2}$ ignition. The hibachi open area is $89 \%$ of the anode area. The construction of the burst diaphragm holder is shown in Dwg. 6 and is supported similarly to the the anode holder, except the rib support spacing is wider. This wider rib spacing provides less support to the foil and allows the burst diaphragm to rupture at a lower overpressure than that necessary to break the anode foil. This then relieves the cell pressure which prevents the anode foil from rupturing. The burst diaphragm also allows $\mathrm{HF}$ gas which is produced during the chemical reaction to be removed quickly from the cell to prevent etching of the windows. V. Design and Construction of Electron-Beam Calorimeter

In order to measure the electron-beam profile and to determine the energy entering the laser cell, a "totally-stopping" calorimeter was designed and constructed. Most totally-stopping calorimeters used in the past were made from carbon. However, since carbon and a number of other materials react with fluorine, new materials were employed for the present calorimeter. The segmented elements of the calorimeter were made of aluminum and were thicker than the range of a $700 \mathrm{kV}$ electron. The material used to insulate the elements were also fluorine compatible. Thus constructed, this was the first capable of measuring electron loss in a fluorine atmosphere.

A photograph of the calorimeter is shown in Fig. 4. Each of the 48 segmented elements is $2.34 \mathrm{~cm} \times 0.56 \mathrm{~cm} \times 0.25 \mathrm{~cm}$ thick. Chrome1-Constantan thermocouples are mechanically attached to each element. The specific heat for Al is $0.214 \mathrm{cal} / \mathrm{gm}^{\circ} \mathrm{C}$, the weight of each element is $0.85 \mathrm{gm}$ and the thermocouple constant is $0.063 \mathrm{mV} /{ }^{\circ} \mathrm{C}$. 


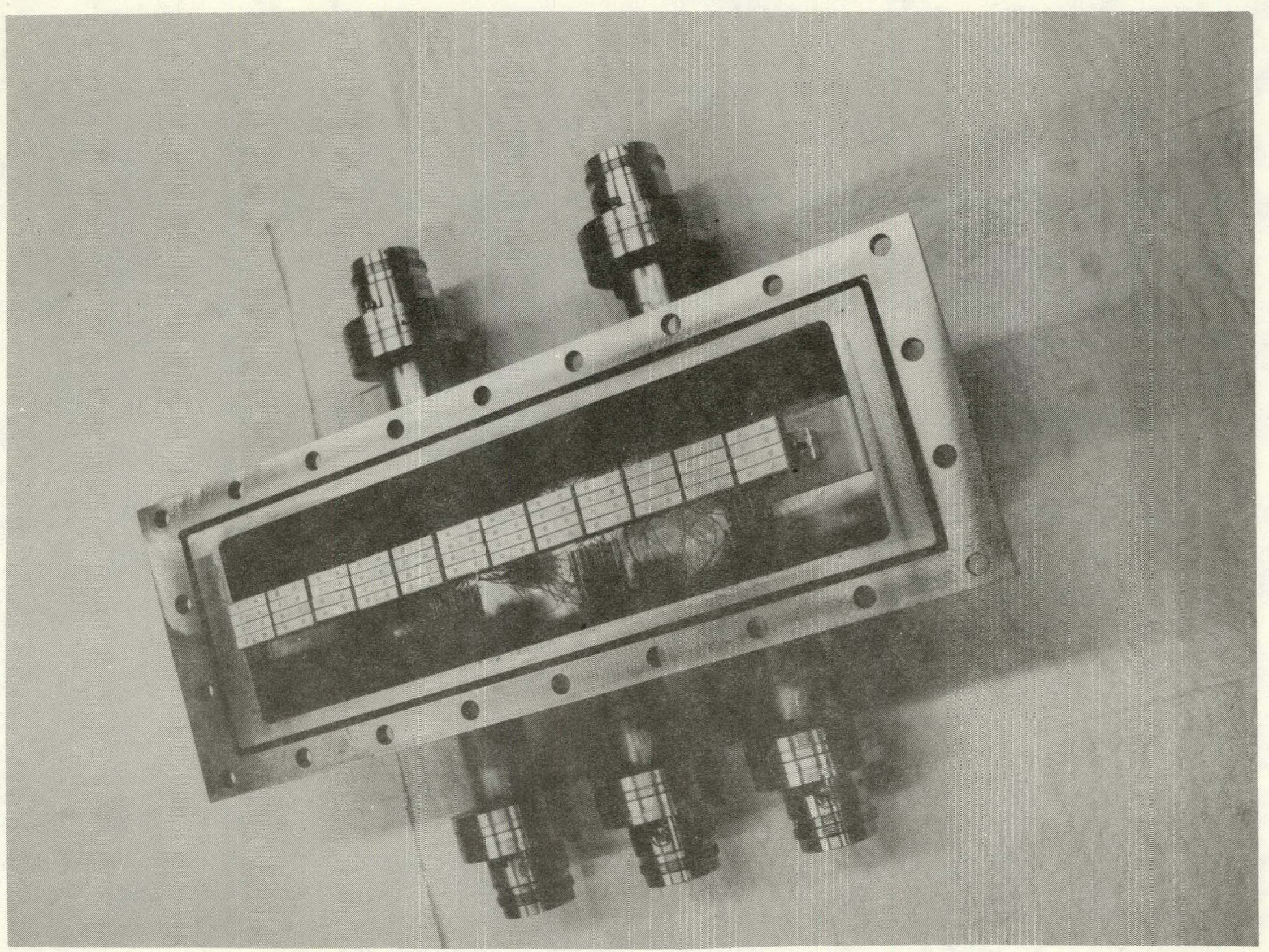

Fig. 4. Photograph of segmerted calorimeter. 
Therefore, the sensitivity of each element of the calorimeter is:

$$
\frac{0.214 \frac{\mathrm{cal}}{\mathrm{gm}^{\circ} \mathrm{C}} \times 0.85 \mathrm{gm} \times 4.186 \frac{\mathrm{J}}{\mathrm{cal}}}{0.063 \frac{\mathrm{mV}}{{ }^{\circ} \mathrm{C}}}=12.086 \frac{\mathrm{J}}{\mathrm{mV}}
$$

The output voltage of each of the elements is recorded on a strip-chart recorder. It was originally envisioned that the calorimeter would be used to determine the deposited energy; however, because of the short electron-beam path length $(2.5 \mathrm{~cm})$ and relatively low pressure used, the amount of the electron-beam energy deposited in the gas was only a few percent of the total energy. This made the measurements difficult, and it was therefore decided to use the calorimeter mainly for uniformity measurements and to use an alternate pressure rise technique to obtain deposited energy.

VI. Measurements

\section{A. Accelerator Measurements}

Initial measurements on the device provided operating characteristics of the machine and a rough estimate of beam uniformity as a function of anode-cathode spacing. A few important machine operating charactersitics measured were: self-breakdown voltage versus pressure for both the spark-gap switches in the Marx and the main switch. The self-breakdown versus pressure curves were very similar to those given in the machine instruction book; therefore, they will not be duplicated here. Diode characteristics were determined at charge voltages of $30,34,36$ and $38 \mathrm{kV}$. The diode energy $\int \mathrm{VIdt} \approx \mathrm{V}_{\max } \mathrm{I}_{\max } \mathrm{T}_{\text {FWHM }}$ as a function of diode voltage is shown in Fig. 5, which indicates a maximum diode energy of $1045 \mathrm{~J}$ at a diode voltage of $518 \mathrm{kV}$ ( $38 \mathrm{kV}$ charge). The actual energy which was measured by the calorimeter placed at the anode under these conditions was $320 \mathrm{~J}$ which means that nearly $70 \%$ of the energy did not enter the laser cell. It is suspected that much of the energy loss in the hibachi; however, some of this energy loss was simply due to the fact that the beam at the anode surface 


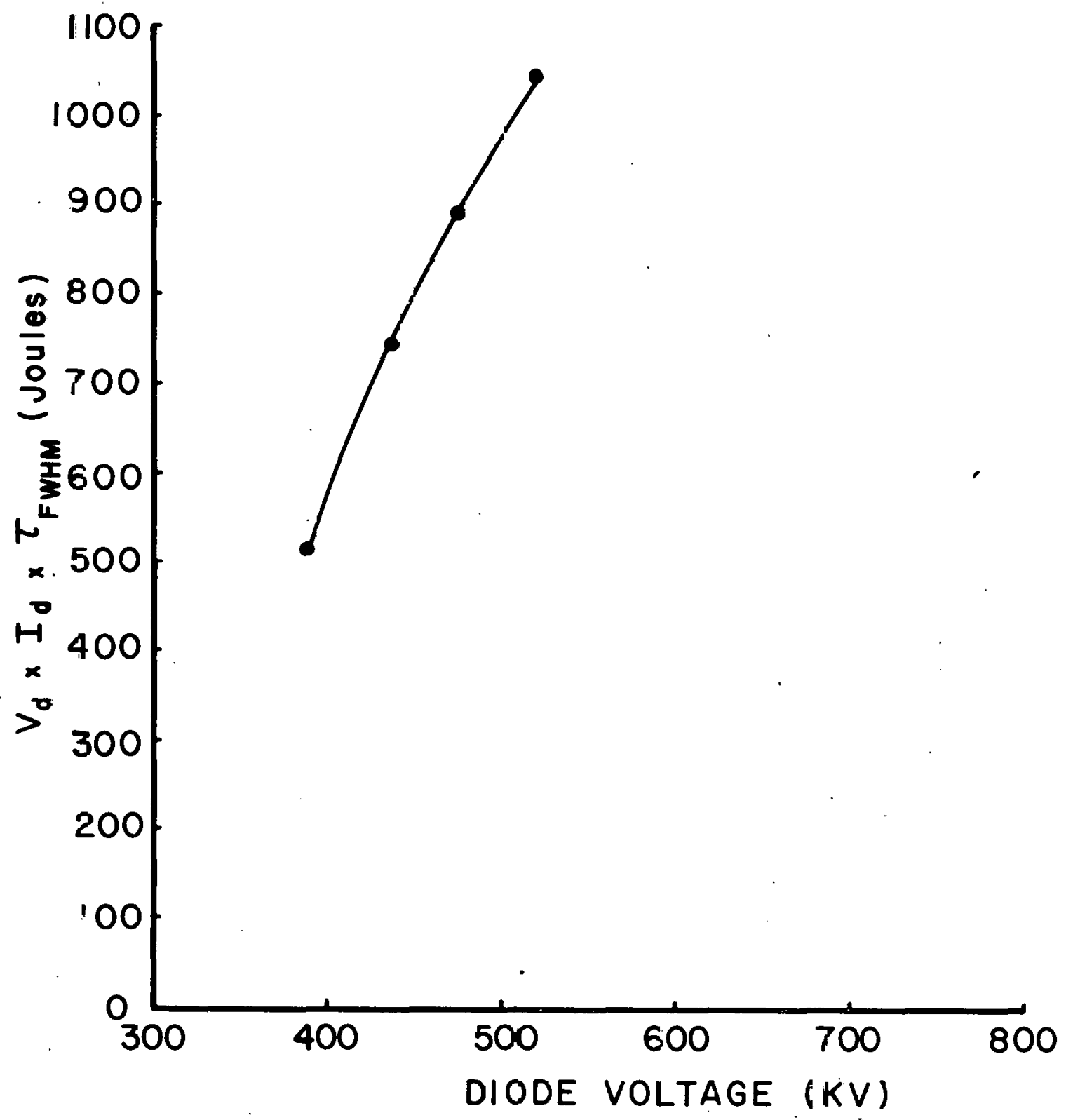

Fig. 5. Diode energy as a function of diode roltages. 
was larger than the opening to the laser cell.

\section{B. Calorimeter Measurements.}

The calorimeter system was used to measure the electron-beam distribution near the anode and to obtain the energy deposition in high pressure $\mathrm{SF}_{6}$. In this case, the amount of energy deposited in the gas is a large fraction of the energy passing through the foil. Figure 6 shows the electron-beam distribution at a distance of $0.16 \mathrm{~cm}$ from the anode. The overall dimensions of the calorimeter are $2.54 \mathrm{~cm}$ by $29.0 \mathrm{~cm}$. The area of the cathode shown in Fig. 1 and in Dwg. 8 is $1.3 \mathrm{~cm}$ by $24.3 \mathrm{~cm}$. As shown by $\mathrm{Fig} .6$, the distribution is peaked in the center, which corresponds to the peak emission area of the cathode. The uniformity across the cell varies by about a factor of two, which is not as good as anticipated, but is sufficient for the initial measurements. The total energy through a 0.001-inch stainless steel anode foll was $319 \mathrm{~J}$ for a diode voltage of $518 \mathrm{kV}$.

Figure 7 shows three electron-beam profiles, taken at the farthest possible distance of $2.29 \mathrm{~cm}(0.9$ inches $)$ from the anode. These profile measurements were taken while using an anode foll of 0.003 inch-thick stainless steel, thereby causing a considerable amount of energy $(\approx 30 \%)$ to be deposited in the foil. This thick foil was necessary to hold the pressure ( $\approx 3000$ Torr) needed for these experiments. The total energy measured at 3 Torr of $\mathrm{SF}_{6}$ at a distance of $2.29 \mathrm{~cm}$ was $168 \mathrm{~J}$, while that at the anode foil was $230 \mathrm{~J}$. This indicates that approximately half of the energy was scattered out of the cell, because the fraction represented by absorption in the gas is negligible at 3 Torr of $\mathrm{SF}_{6}$. The profiles shown in Fig. 7 are much more uniform away from the anode than at the anode which indicates a lot of scattering since scattering tends to make the distribution more uniform. The lower two distributions shown in Fig. 7 give the energy absorbed by the calorimeter when 3000 Torr of $\mathrm{SF}_{6}$ is present in the cell. 


\begin{tabular}{|c|c|c|c|c|c|c|c|c|c|c|c|}
\hline 1.3 & 5.3 & 7.1 & 7.8 & 6.0 & 6.6 & 5.4 & 5.7 & 7.1 & 5.7 & 7.3 & 4.8 \\
\hline 2.4 & 9.6 & 8.5 & 10.3 & 11.5 & 12.1 & 9.1 & 10.1 & 8.4 & 10.2 & 10.9 & 6.0 \\
\hline 1.8 & 5.4 & 9.6 & 8.4 & 7.9 & 4.8 & 7.9 & 8.2 & 8.7 & 8.0 & 8.5 & 2.4 \\
\hline 1.4 & 3.5 & 5.5 & 4.4 & 6.0 & 6.0 & 6.0 & 5.8 & 5.5 & 4.8 & 6.0 & 2.4 \\
\hline & & $\begin{array}{l}\text { MARX } \\
\text { DISTA }\end{array}$ & $\begin{array}{l}\text { HARC } \\
\text { E FF }\end{array}$ & $\begin{array}{l}38 \mathrm{~K} \\
\text { ANO }\end{array}$ & & & & & 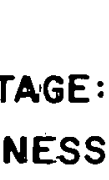 & $\begin{array}{l}0 \mathrm{KV} \\
025\end{array}$ & \\
\hline
\end{tabular}

Fig. 6. Electron-bəam distribution near the anode. 
\begin{tabular}{|l|l|l|l|l|l|l|l|l|l|l|l|l|l|l|l|l|l|l|l|}
\hline 1.6 & 3.3 & 3.7 & 3.9 & 3.0 & 4.2 & 3.2 & 3.2 & 3.9 & 3.8 & 3.0 & 1.8 \\
\hline
\end{tabular} \begin{tabular}{|l|l|l|l|l|l|l|l|l|l|l|l|l|l|l|}
\hline 2.8 & 3.8 & 4.5 & 4.1 & 4.2 & 4.8 & 4.0 & 4.6 & 4.6 & 4.1 & 4.2 \\
\hline
\end{tabular} \begin{tabular}{|l|l|l|l|l|l|l|l|l|l|l|l|}
\hline 2.4 & 3.7 & 4.9 & 4.4 & 4.2 & 4.2 & 4.0 & 4.3 & 4.6 & 4.5 & 4.2 & 1.2 \\
\hline
\end{tabular} \begin{tabular}{|l|l|l|l|l|l|l|l|l|l|l|l|l|l|l|l|l|l|}
\hline 1.0 & 2.2 & 3.4 & 2.8 & 4.2 & 4.2 & 2.6 & 3.1 & 3.6 & 3.0 & 3.6 & 1.2 \\
\hline
\end{tabular} 3 Torr $S F_{G} \quad E_{T}=168 \mathrm{~J}$

\begin{tabular}{|c|c|c|c|c|c|c|c|c|c|c|c|}
\hline 1.5 & 1.7 & 1.3 & 1.7 & 1.2 & 1.8 & 1.3 & 1.5 & 1.6 & 1.4 & 0.6 & 1.2 \\
\hline 2.0 & 1.5 & 2.0 & 1.8 & 1.8 & 2.4 & 1.5 & 2.0 & 2.2 & 1.7 & 1.8 & 1.2 \\
\hline 1.3 & 1.8 & 2.3 & 2.0 & 1.8 & 1.7 & 1.5 & 1.8 & 2.1 & 1.7 & 1.2 & 1.2 \\
\hline 0.3 & 0.9 & 1.4 & 1.5 & 1.8 & 1.8 & 0.5 & 1.0 & $\begin{array}{l}1.5 \\
\end{array}$ & 0.8 & 1.2 & \begin{tabular}{|l}
1.2 \\
\end{tabular} \\
\hline
\end{tabular}

\begin{tabular}{ll|l|l|l|l|l|l|l|l|l|l|l|}
\hline 0.9 & 1.6 & 1.3 & 1.5 & 0.6 & 1.2 & 1.0 & 0.9 & 1.5 & 1.3 & 0.6 & 0.6 \\
\hline
\end{tabular} \begin{tabular}{llllllllllllll}
\hline 1.6 & 1.2 & 1.7 & 1.6 & 1.8 & 1.8 & 1.3 & 1.8 & 2.0 & 1.5 & 1.2 & 0.6 \\
\hline
\end{tabular}

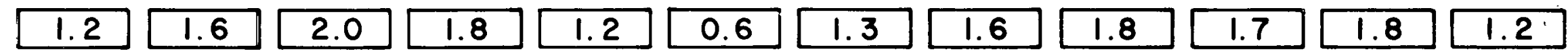
\begin{tabular}{|l|l|l|l|l|l|l|l|l|l|l|l|}
\hline 0.2 & 0.6 & 0.9 & 0.8 & 1.8 & 1.2 & 0.3 & 0.8 & 1.3 & 0.9 & 0.6 & 0.6 \\
\hline
\end{tabular} 3000 Torr $\mathrm{SF}_{6} \quad E_{T}=59 \mathrm{~J}$

MARX CHARGE: $38 \mathrm{KV}$

DIODE VOLTAGE: $700 \mathrm{KV}$

DISTANCE FROM ANODE: $2.29 \mathrm{~cm}$

FOIL THICKNESS : $0.076 \mathrm{~mm}$ 
Here again the distributions are more or less unfform away from the anode. The difference in the transmitted energy at the anode at 3000 Torr (73 J and $59 \mathrm{~J})$ represent the accuracy of the measurements and the reproducibility of the electron-beam machine. The difference between the transmitted energy using 3 Torr $\mathrm{SF}_{6}$ and 3000 Torr $\mathrm{SF}_{6}$ gives an upper bound for the energy deposited in the 3000 Torr $\mathrm{SF}_{6}$. These values of 95 and $109 \mathrm{~J}$ obtained by calorimetry will be compared to the pressure rise measurements explained in the next section.

\section{Pressure Rise Measurements}

In order to determine the energy deposited in the cell at lower pressures, a pressure rise technique was used. If energy is added to an ideal gas of a constant volume (V), the temperature (T) will rise according to $P V=N R T$. The pressure rise is given by $T / T=P / P$. Since the energy deposited is related to the change in temperature by $E_{\text {dep }}=C_{v} \Delta T$, then

$$
\mathrm{E}_{\mathrm{dep}}=\mathrm{C}_{\mathrm{v}} \mathrm{T}\left({ }^{\circ} \mathrm{K}\right) \frac{\Delta \mathrm{r}}{\mathrm{P}} \frac{\mathrm{ca} \perp}{\mathrm{gm}}
$$

where $\bar{c}_{\mathrm{y}}$ is the specific heat at constant volume, $T$ is the trmperature in degrees kelvin, $\mathrm{P}$ is the initial pressure and $\Delta \mathrm{P}$ is the measured pressure rise. Equation (2) will be valid whenever processes like radiation are not important. Comparisons of the deposited energy by this pressure rise technique and with total stopping calorimeters have been made on the $\lambda-3$ device. ${ }^{6}$ Good agreement was obtained for $\mathrm{N}_{2}$; however, the pressure rioc measurements for argon, which radiates up to $40 \%$ of 1 ts energy, gave deposition values smaller than those obtained by argon deposition scaled from $\mathrm{N}_{2}$. In general, the pressure rise measurements are made in nitrogen and results for other gases are scaled according to density.

The pressure rise is measured for the entire volume including the excited 
and unexcited regions. In order to determine the energy density deposited In the excited regic, alone, Eq. (2) should be multiplied by the ratio of the unexcited to excited volume.. In our case, $0.531 \ell / 0.234 \&$. One must use this value to determine energy expended per F atom, which will be discussed later. Pressure-rise measurements were performed in nitrogen at a variety of diode voltages and in other gases $\left(F_{2}\right.$ and $\left.S_{6}\right)$ at the maximum diode voltage of $518 \mathrm{kV}$. Figure 8 shows $P$ as a function of pressure for four different Marx charge voltages, corresponding to diode voltages of $390 \mathrm{kV}$, $437 \mathrm{kV}, 475 \mathrm{kV}$ and $518 \mathrm{kV}$. The data shows that $\Delta \mathrm{P}$ is Iinear with pressure up to total pressures of 2400 Torr of $\mathrm{N}_{2}$. The fact that $\Delta \mathrm{P}$ is linear means the deposited energy at a given voltage scales with density. This should be the case if $o l$ is much less than the range of the electron where $\rho$ is the density and $l$ is the transverse dimension of the cell. The slope of the lines in Fig. 8 is related to the energy deposited in the laser cell in joules/l-atm. This value is important in chemical laser research since it determines the initiation level or the fractional amount of dissociation. This relationship is obtained from Eq. (2) and is given by

$$
\dot{\mathrm{E}}_{\text {deposited }}=0.171 \mathrm{MC}_{\mathrm{v}}^{\mathrm{T}}\left(\frac{\Delta \mathrm{P}}{\mathrm{P}}\right) \frac{\mathrm{J}}{\ell-\text { atm }}
$$

where

$$
\begin{aligned}
\mathrm{M} & =\text { molecular weight } \\
\mathrm{C}_{\mathrm{v}} & =\text { specific heat at constant volume } \\
\mathrm{T} & =\text { temperature in } \mathrm{O}_{\mathrm{K}}
\end{aligned}
$$

for $\mathrm{N}_{2}$

$$
\mathrm{M}=28 \text { and } \mathrm{C}_{\mathrm{v}}=0.178 \frac{\mathrm{cal}}{\mathrm{gm}^{\circ} \mathrm{K}}
$$




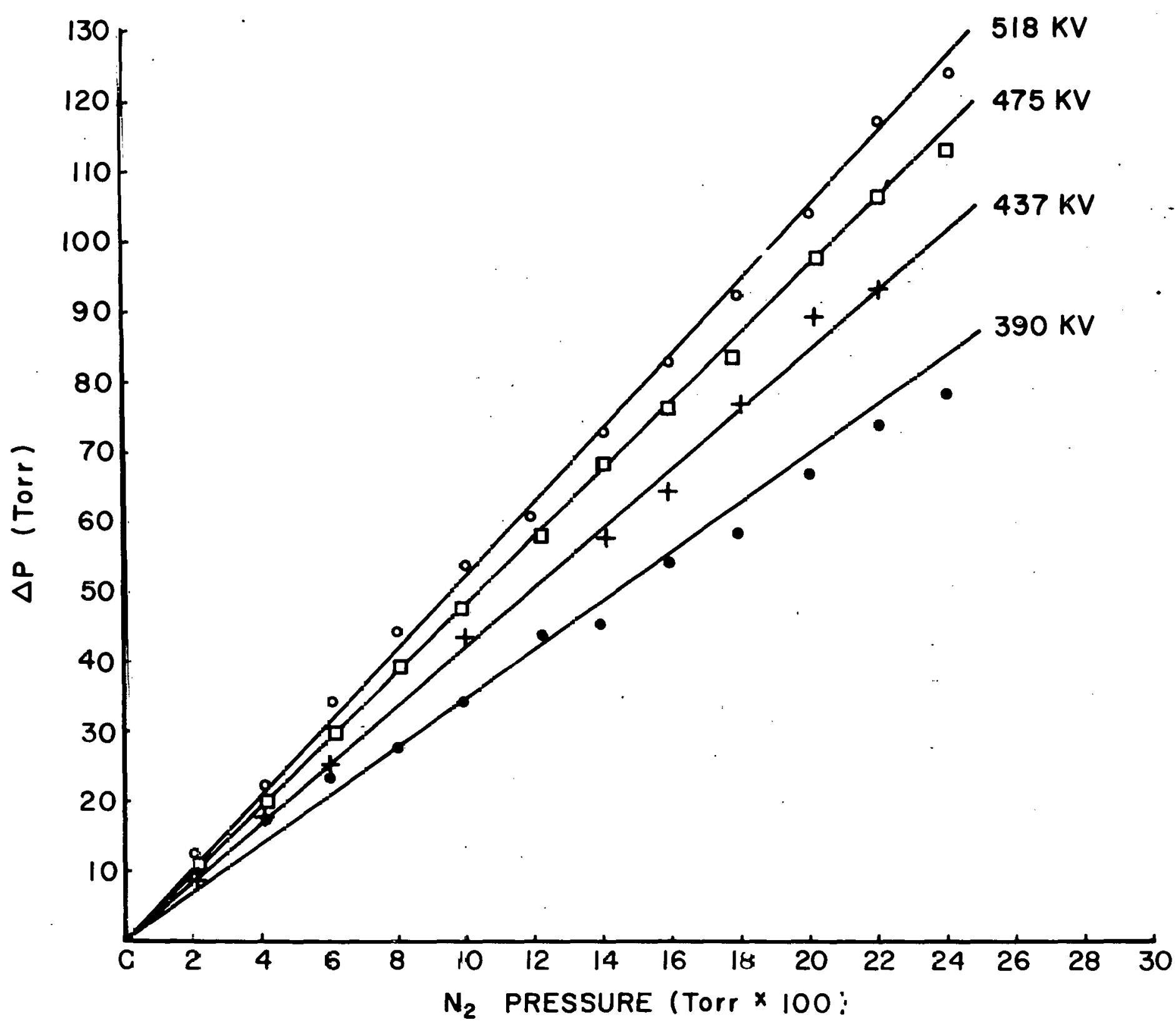

Fig. 8. Pressure rise as a function of nitrogen pressure at various diode voltages. 


$$
E_{\text {deposited }}=255 \frac{\Delta P}{P}
$$

In order for this to be useful for laser calculations, one has to multiply this by the ratio of total volume to active volume, in this case 2.29. Then $E_{\text {deposited }}=584 \Delta P / P$. A plot of energy deposited in $\mathrm{J} / \mathrm{l}-\mathrm{atm} \mathrm{N}_{2}$ as a function of diode voltage is shown in Fig. 9. The maximum deposition level is $31 \mathrm{~J} / \ell-a t m N_{2}$ which is simflar to that of large chemical laser systems. The curve shown in Fig. 9 increases with increasing diode voltage, even though less energy would be deposited if the total energy in the diode was held constant. In our device, the total energy increased from $515 \mathrm{~J}$ at a diode voltage of $390 \mathrm{kV}$ to $1045 \mathrm{~J}$ at a diode voltage of $518 \mathrm{kV}$. In other words, the input energy increased by a factor of 2.0 while the deposition only increased by a factor of 1.4 .

The basic approach of the pressure rise technique is to measure the pressure rise in nitrogen (where calorimeter measurements have been shown to agree) and then density scale these results to other gases, such as argon and fluorine. In an effort to determine if the pressure rise technique could be applied to other gases, measurements were also made in $F_{2}$ and $\mathrm{SF}_{6}$ since these are the gases of interest for chemical laser research. Figure 10 shows $\Delta P$ as a function of pressure for these three gases at a diode voltage of $518 \mathrm{kV}$. Using Eq. (3) with $\mathrm{M}=28, \mathrm{C}_{\mathrm{v}}=0.178 \mathrm{cal} / \mathrm{gm}^{\mathrm{o}} \mathrm{K}$ for $\mathrm{N}_{2}, \mathrm{M}=38$, $C_{v}=0.146 \mathrm{cal} / \mathrm{gm}^{\circ} \mathrm{K}$ for $F_{2}$ and $M=146$ and $C_{v}=0.145 \mathrm{cal} / \mathrm{gm}^{\circ} \mathrm{K}$ for $\mathrm{SF}_{6}$, together with a volume of 0.531 , the deposition was calculated for each pressure shown in Fig. 10. In order to determine if density scaling is correct, the energy deposited is plotted against $\rho l$, where $\rho$ is the density at each pressure and $\ell$ is the absorption length of the cell. In this case, 


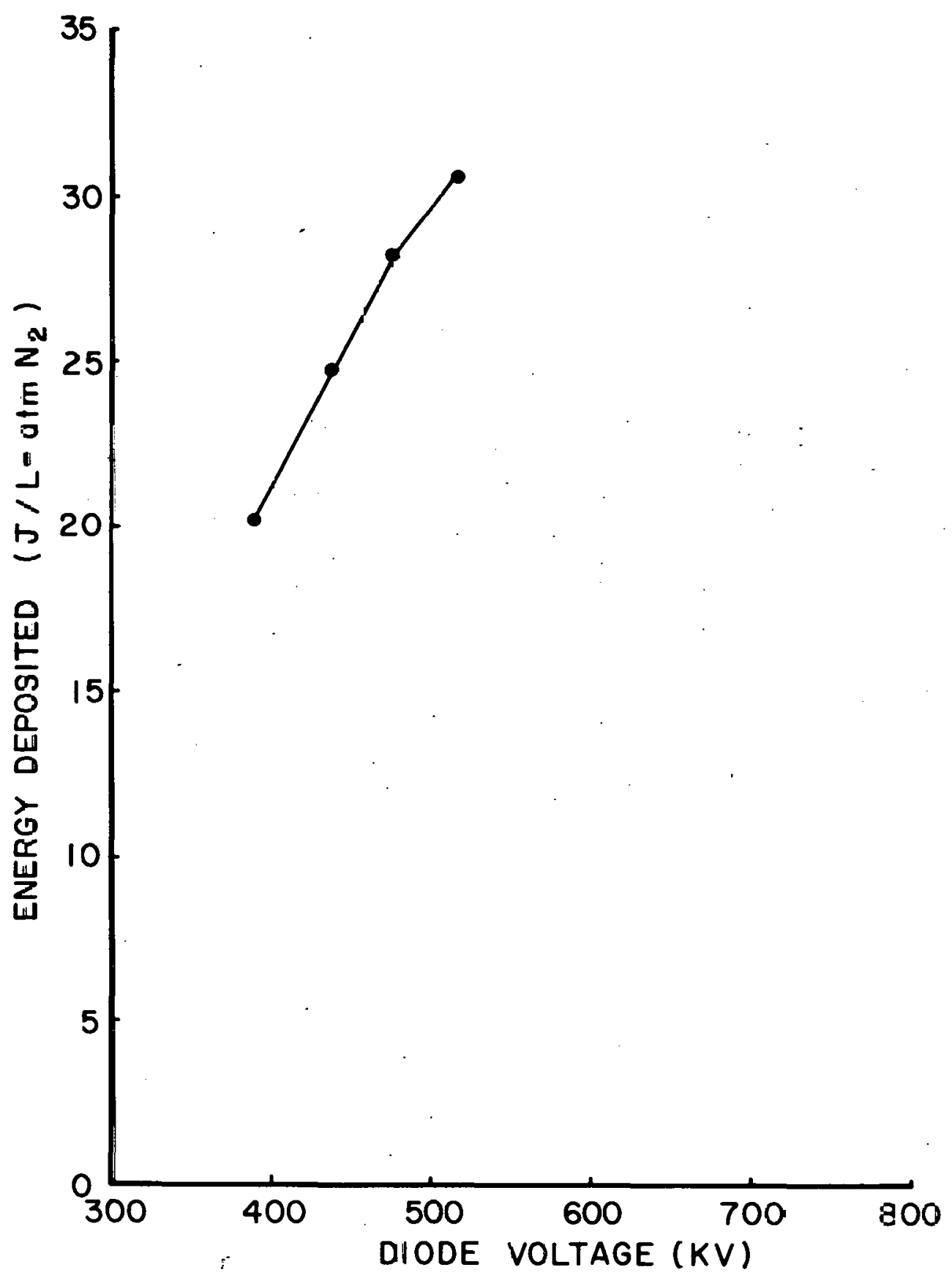

Fig. G. Deposited energ in nitrogen as a function of ciode vcltage. 


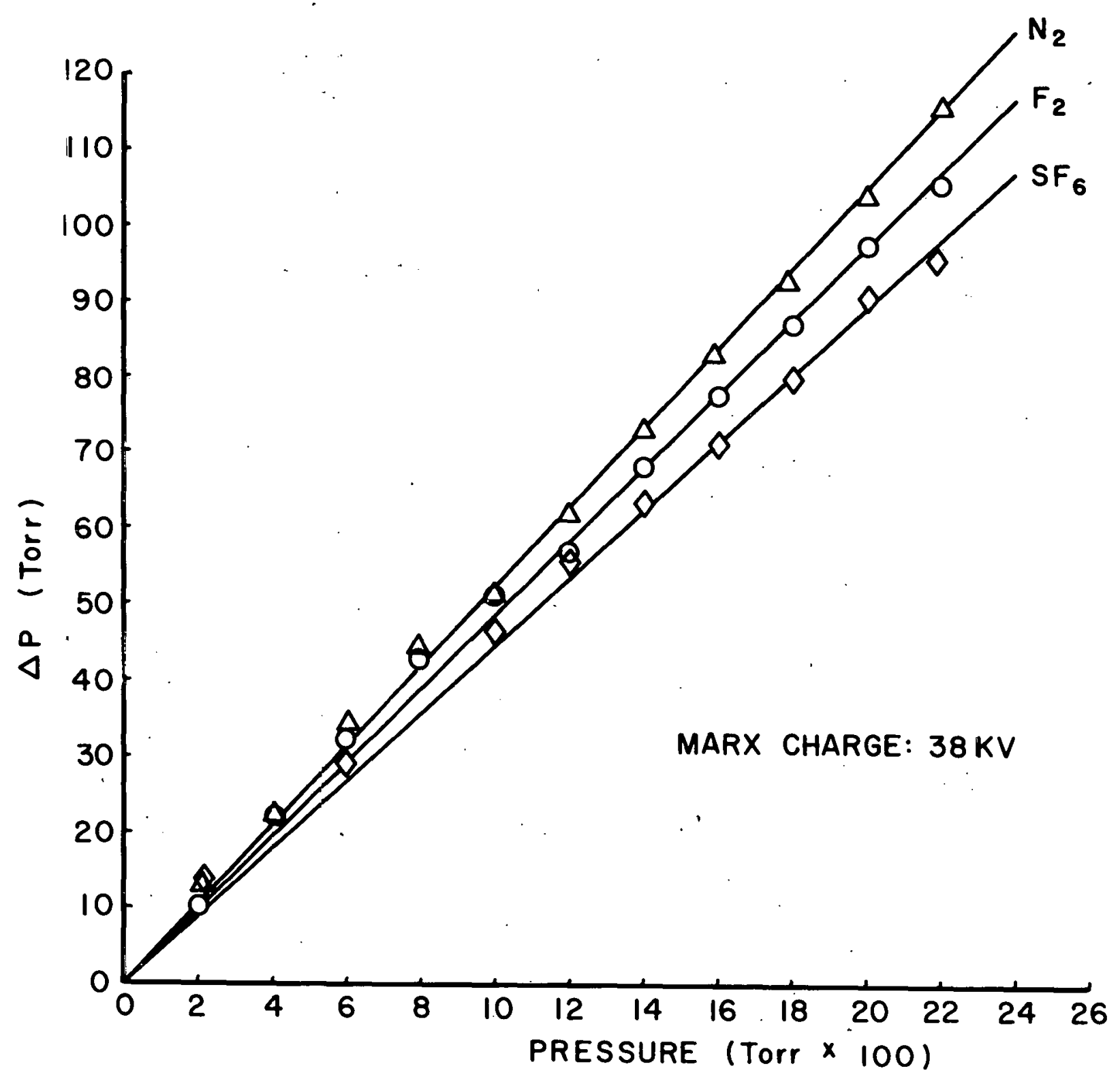


$\ell=2.54 \mathrm{~cm}$. The results, plotted in $\mathrm{FIg} .11$, show that the deposited energy as deduced by the pressure rise in $F_{2}$ and $\mathrm{SF}_{6}$ fall below that predicted by a density scaling of $\mathrm{N}_{2}$, shown by the dashed 1 ine. There appears to be an, error of $\approx 50 \%$ at the highest $\mathrm{SF}_{6}$ pressure if $\ddot{N}_{2}$ data is used. However, for deposition values for $0 \leq \rho \ell \leq 0.4$ where most of our laser and kinetic data were obtained, the error is insignificant. One possibility for the disagreement at high pressures is that there is a significant amount of scattering in $\mathrm{SF}_{6}$, which was pointed out in the calorimeter studies and much of the initial energy was scattered out of the cell. The upper bound to the energy deposited at 3000 Torr $\mathrm{SF}_{6}$ was obtained with the calorimeter system shown in Fig. 11. This measurement would suggest that the pressure rise measurement in $\mathrm{SF}_{6}$ agrees with the calorimeter data and supports the scattering argument. It should be pointed out that a plot such as the one shown in Fig. 11 1s only logical if the electron range in all the gases is simflar. The range of a $500 \mathrm{kV}$ electron varies from about $0.2 \mathrm{gm} / \mathrm{cm}^{2}$ to $\approx 0.4 \mathrm{gm} / \mathrm{cm}^{2}$, which is roughly a factor of 10 larger than the highest $\rho \&$ in these studies.

The conclusion, therefore, from these pressure rise measurements is that it appears $F_{2}, N_{2}$ and $\mathrm{SF}_{6}$ give roughly the same deposition values for the pressures of interest for laser studies, 1.e., 100 Torr $\mathrm{SF}_{6}$ or 500 Torr $\mathrm{F}_{2}$, and can be scaled from $\mathrm{N}_{2}$ measurements. The disagreement at high pressures of $\mathrm{SF}_{6}$ can be explained by scattering since the pressure rise appears to agree with calorimeter measurements.

D. Laser Measurements

A limited number of laser shots were performed to check out the laser system. An optical cavity was formed using a flat sapphire output coupler and a totally reflecting flat copper mirror. The gas mixture for these shots was 


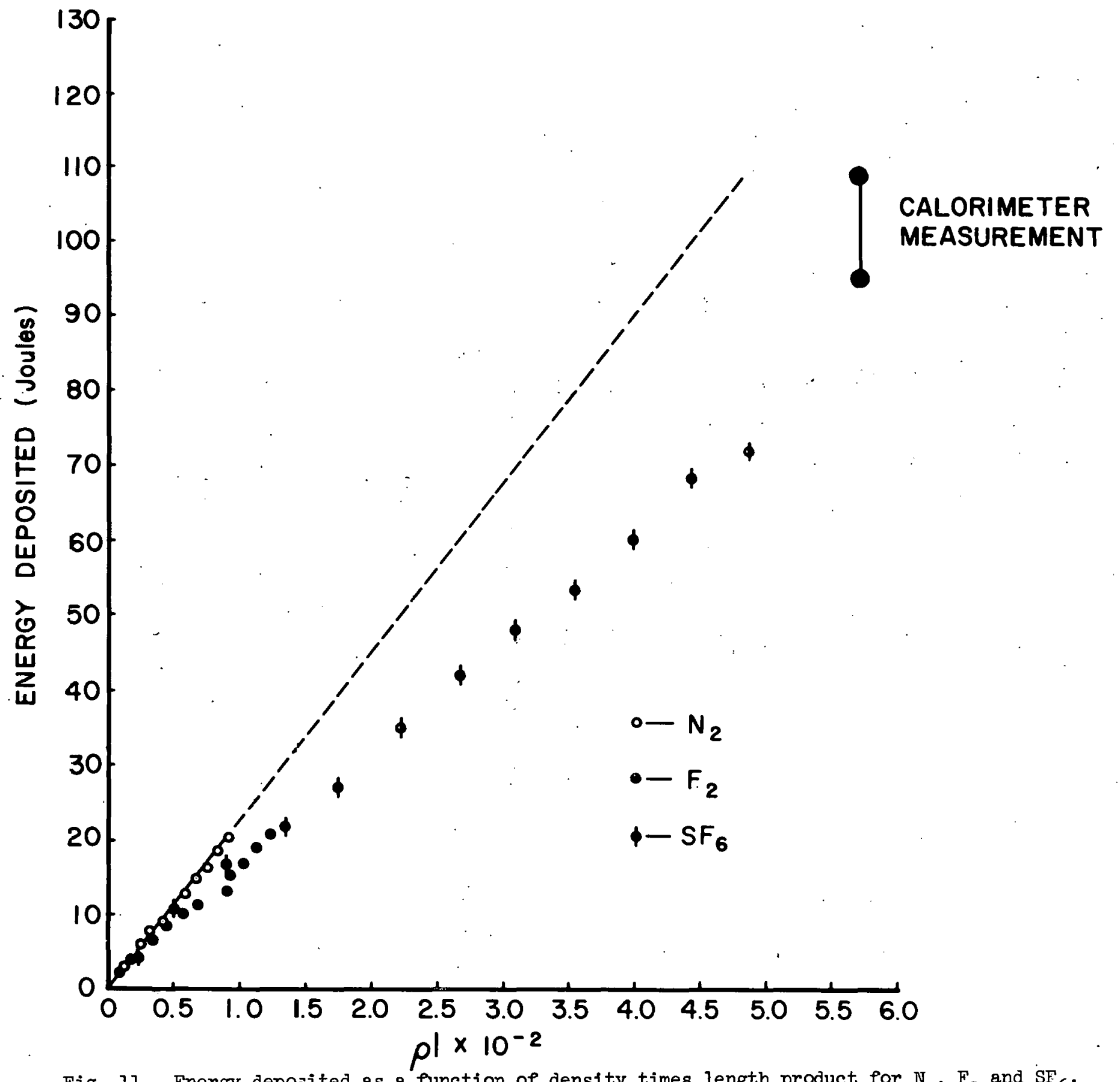

Fig. 11. Energy deposited as a function of density times length product for $\mathrm{N}_{2}, \mathrm{~F}_{2}$ and $\mathrm{SF}_{6}$. 
500 Torr $\mathrm{F}_{2}, 150$ Torr $\mathrm{O}_{2}$ and 125 Torr $\mathrm{H}_{2}$. Measurements included laser pulse width, laser energy and intensity distribution usine "foot print" paper. The electron beam current and laser pulse time histories are shown in Fig. 12. The diode voltage for these shots was $390 \mathrm{kV}$. The laser pulse width is much longer than the electron beam pulse width as is expected using the present initiation levels. The total laser energy at this pressure and gas mixtures was $3.84 \mathrm{~J}$. Using the deposition for an equivalent nitrogen pressure of 859 Torr, the energy deposited in the gas was $8.89 \mathrm{~J}$, yielding an electrical efficiency of $43 \%$, which is reasonable for HF chemical lasers. The "foot print" of the output showed that the laser medium did not have any hot spots, which also agreed with our uniformity measurements.

\section{E. Other Measurements}

The apparatus was also used to measure the optical absorption of the $\mathrm{P}_{1}$ (7) line of $\mathrm{HF}$ as a function of $\mathrm{HF}$ pressure in order to compare with previous measurements. The energy expended per fluorine atom in $\mathrm{SF}_{6}-\mathrm{H}_{2}\left(\mathrm{C}_{2} \mathrm{H}_{6}\right)(\mathrm{HCl})$ gas mixtures was also determined. This experiment involved measuring the amount of HF produced when the electron beam excited these mixtures. The results of these two series of experiments will be published in the near future.

VII. Conclusions

The T-3 laser system, designed for HF/DF chemical laser studies, is described herein. The system performance was outlined with particular attention paid to beam uniformity and energy deposition. The diagnostics for measuring the system performance were chiefly calorimetry and pressure rise experiments, both of which were discussed in detail. Finally, some HF laser experiments done with the T-3 system are briefly outlined along with their results. 


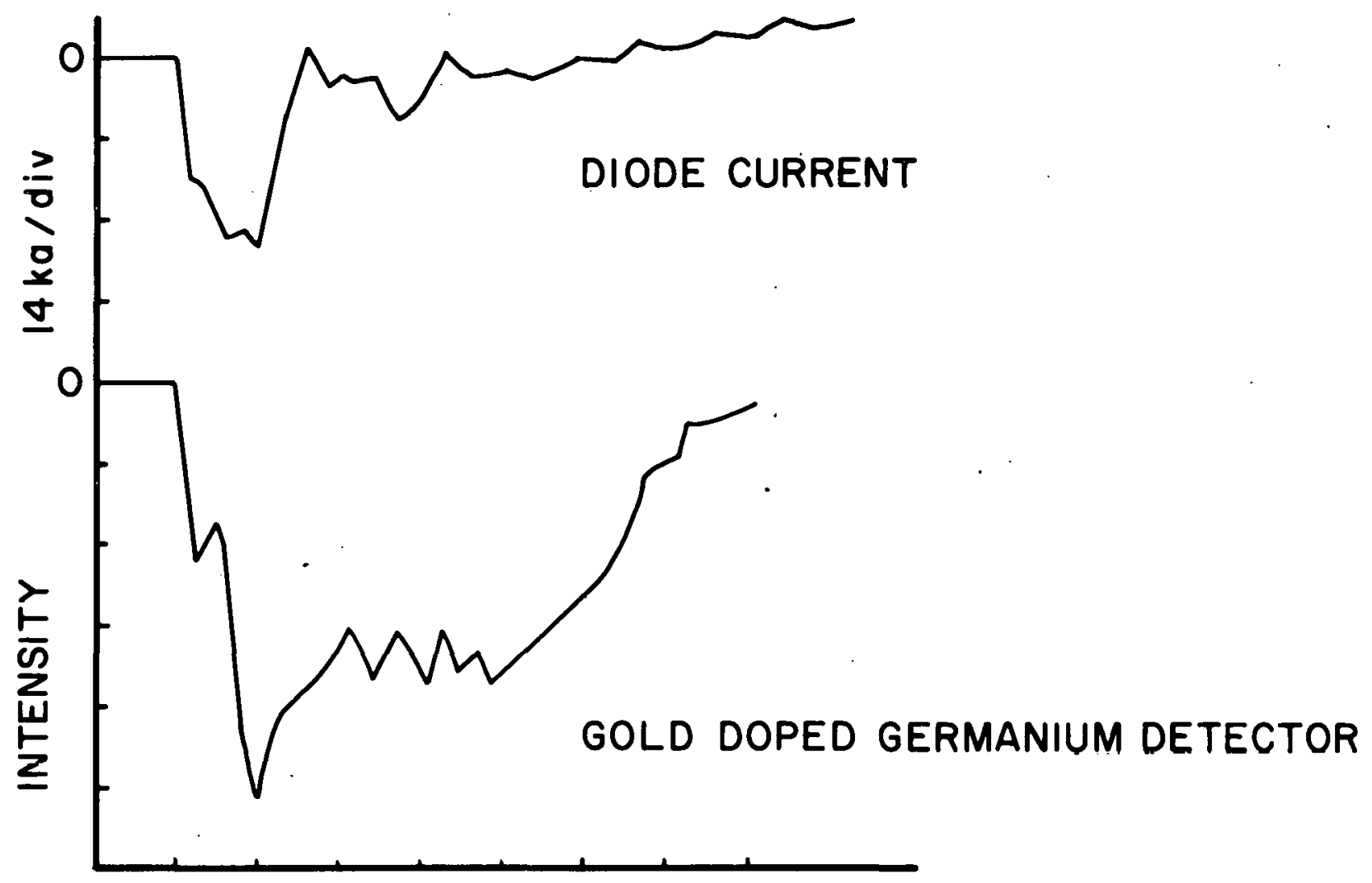

50 ns / div

$\checkmark$

Fig. 12. Electron-beam current and laser intensity time histories. 


\section{REFERENCES}

1. Physics International Company, San Leandro, CA, PI Report No. PIMM 893.

2. A. K. Hays, J. M. Hoffman, and G. C. Tisone, "Development of A Pulse-Per-Second KrF Laser," SAND76-0422, Sandia National Laboratories, Albuquerque, NM, November 1976.

3. R. A. Klein, "Gas Handling System for Sandia HF Laser Facility," Internal Memorandum, Sandia National Laboratories, Albuquerque, NM 87185, Masclı 1979.

4. Physics International, San Leandro, CA, TG-70 Pulse Generator.

5. Cinemoid, Holtzmueller Corporation, 2545 16th Street, San Francisco, CA 94103.

6. G. C. Tisone and E. L. Patterson, private communication. 

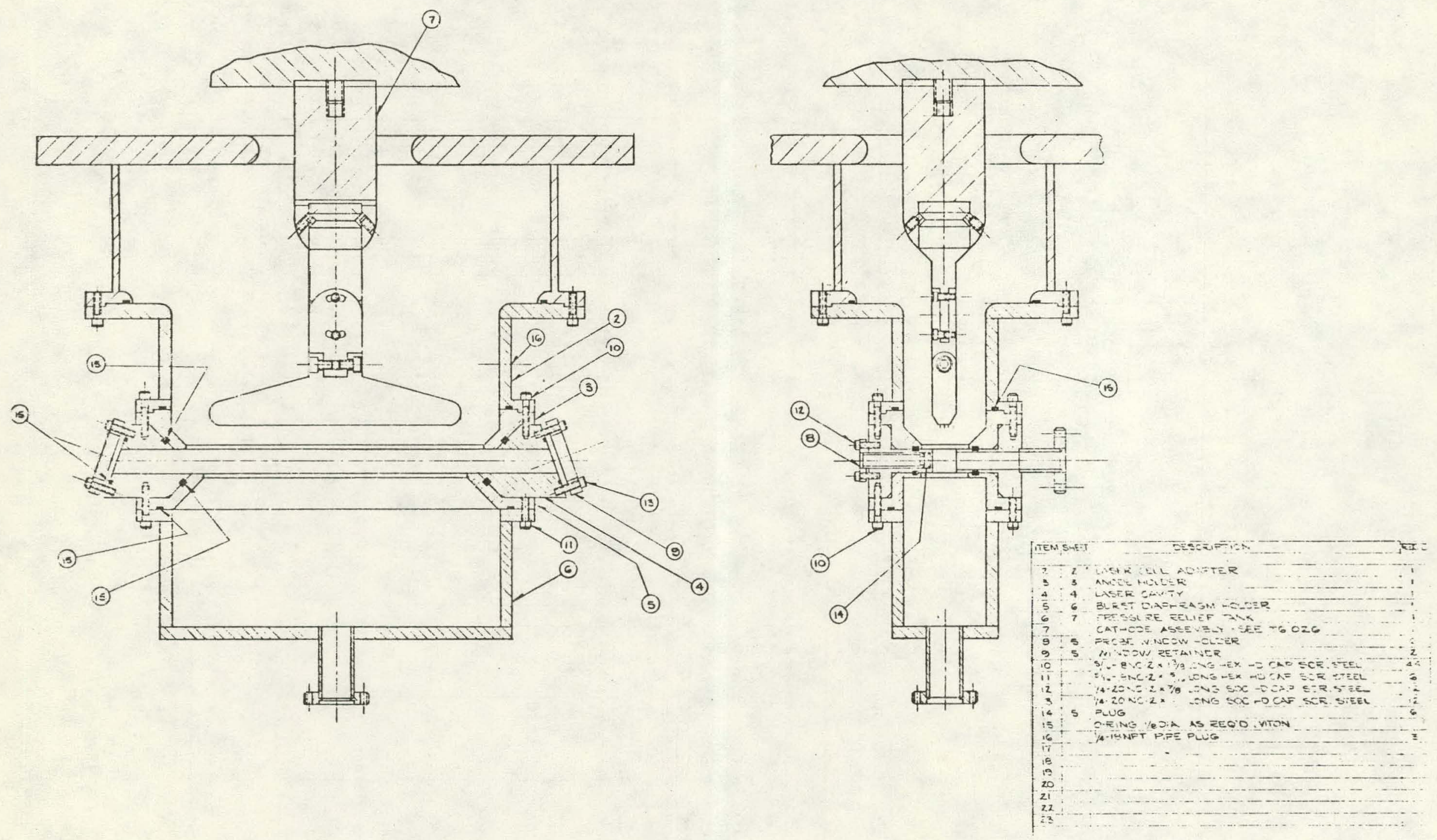


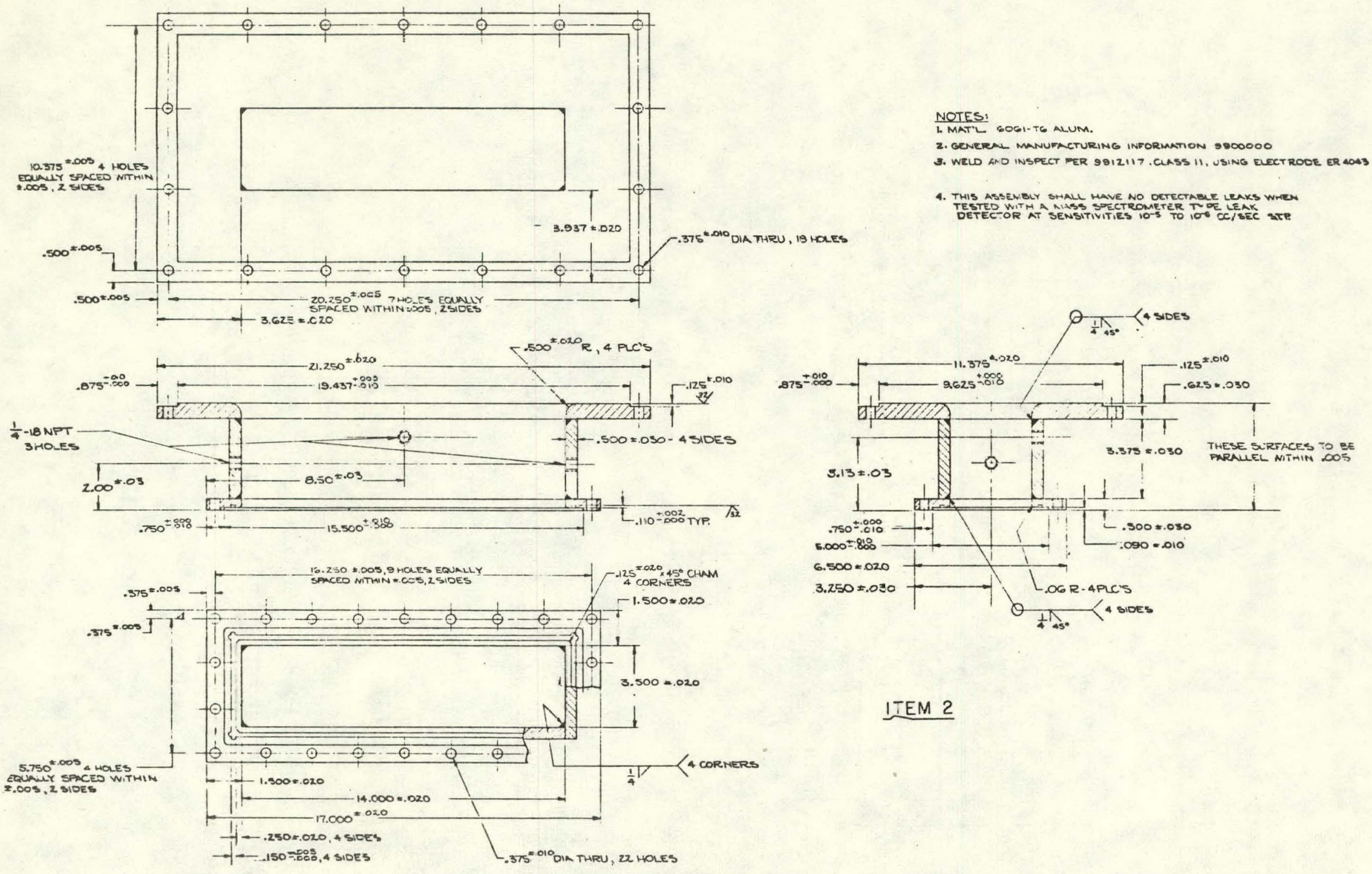

Dwg. 2. Leser Cell Adapter (PPS) 


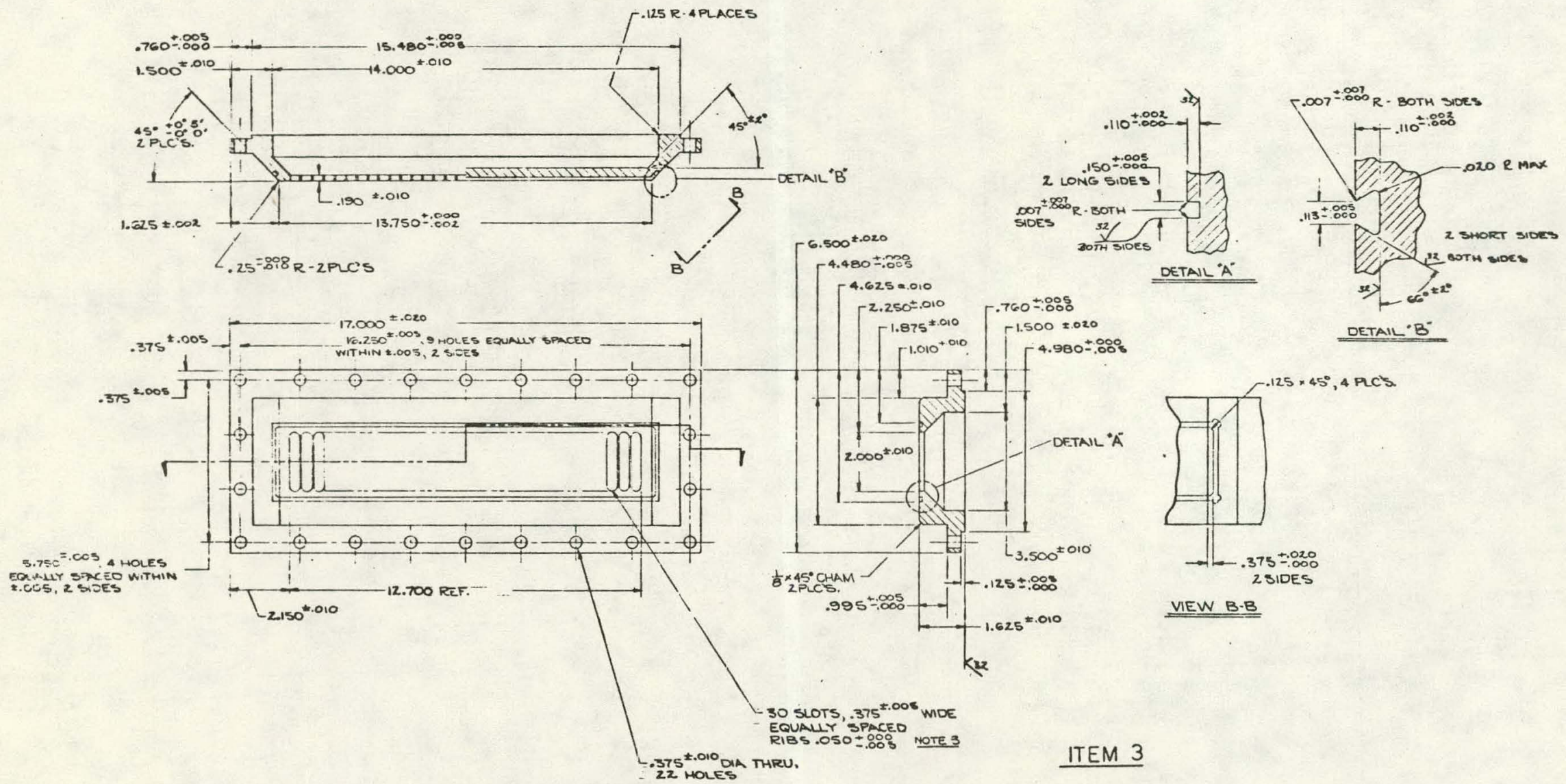



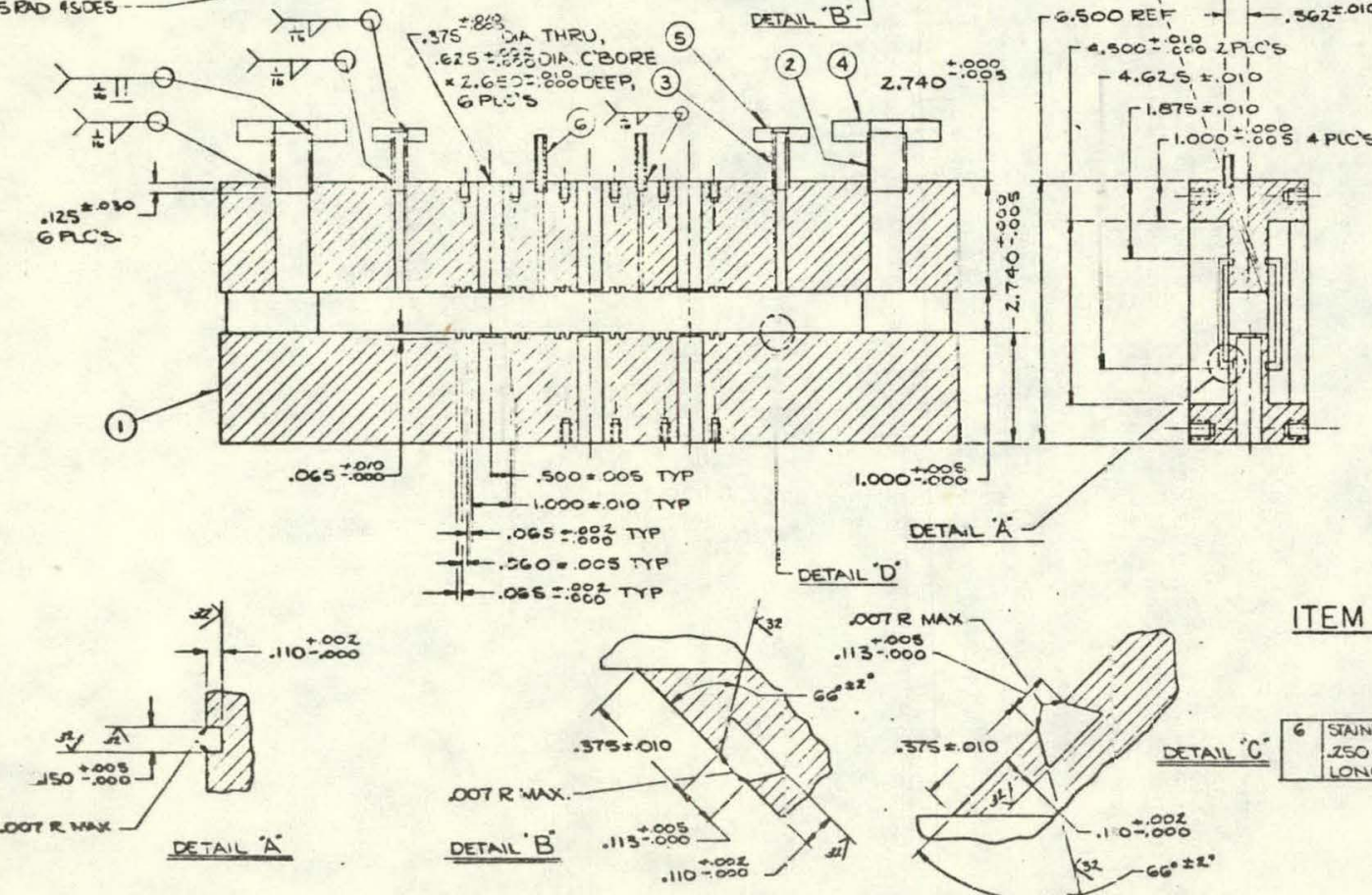

$\underline{\text { ITEM }<}$

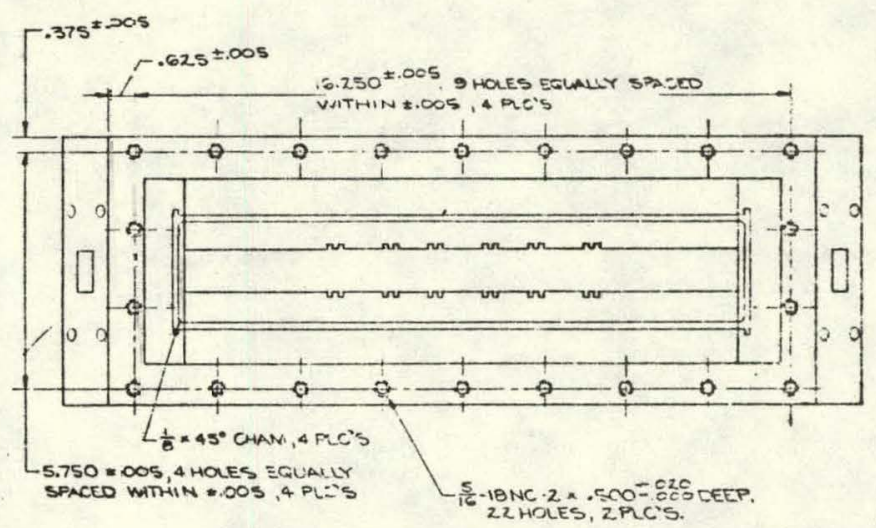

CENER MANUFACTURING NCTES

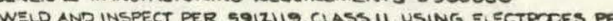
ASTMA 298 . CLASS E30B-IS OR BARE ELECTROCE PER MIL-E- 3933 TAPE MIL-3CB S THALL HAVE, NO DETECTABLE EAKS NHEN-ESTED WITH A NASS SPECTEOMETER TIPE LEAN TETECTOR AT SEMSTIVTTES THS TO $10^{\circ}$ CCL/ SEC S.TP

5. THIS FINISH IPHONO FINISHI IS TO BE APPLIEO TO AL US $=E$

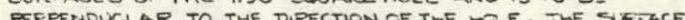

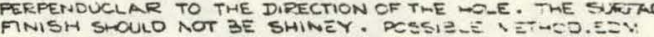
THIS F INISH TO BE APPLLED BEFCEE HOLES ARE ZRILEO NTO 1.00 SQ HOLE, AND .06S SLOTS ARE MACHINED.

Dwg. 4. Laser Cavity (PPS) 


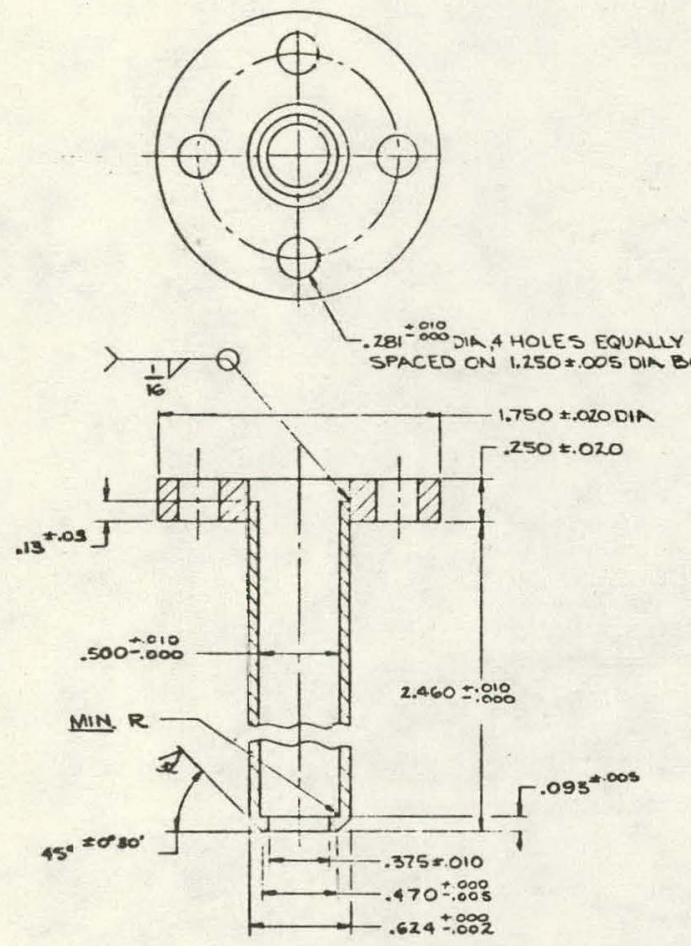

PROBE WINDOW HOLDER MATL' $3 C 3$ STAINLESS STL

$$
\text { GEEQ'D }
$$

\section{ITEM 8}

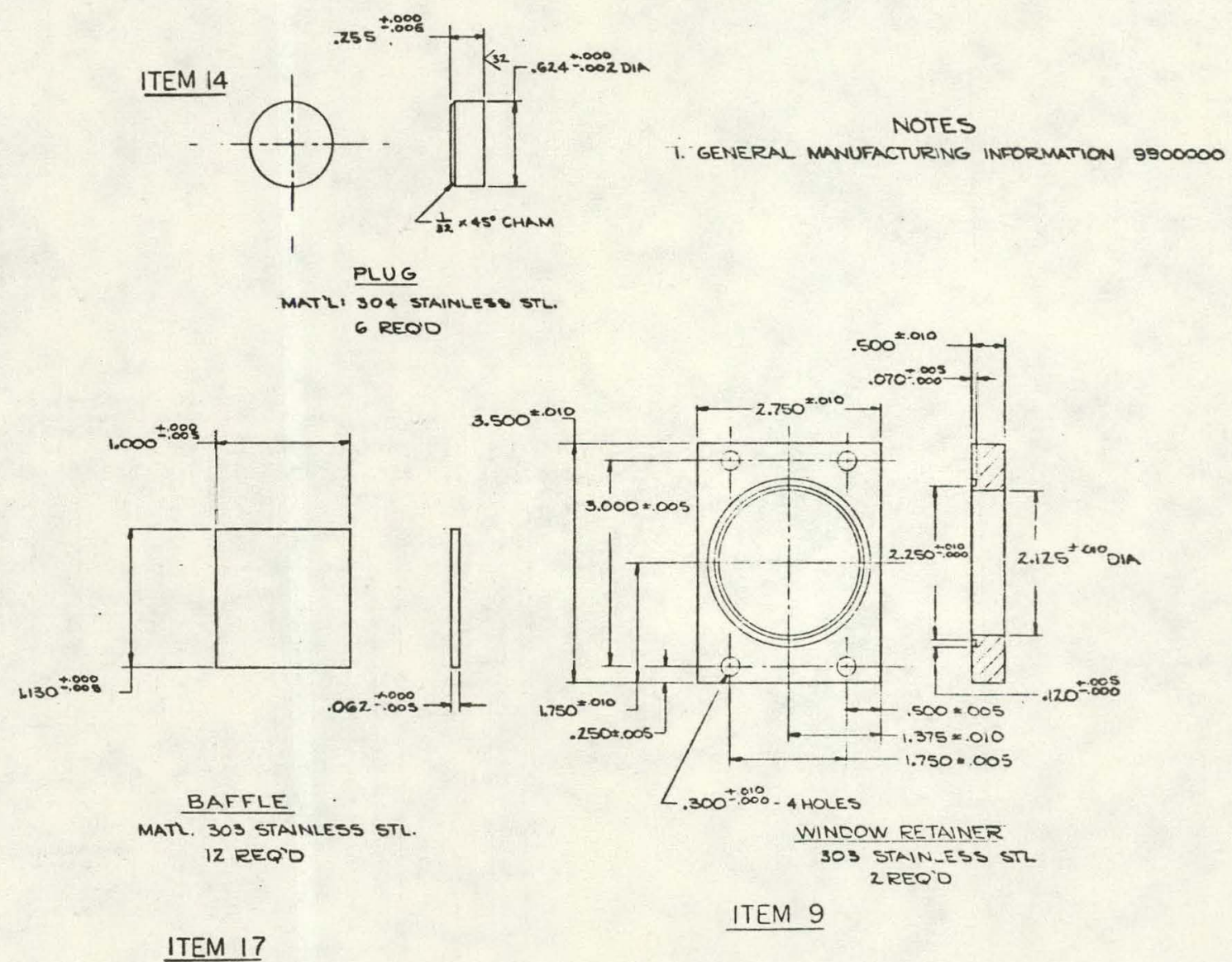

Dwg. 5. Laser Cavity (PPS) 


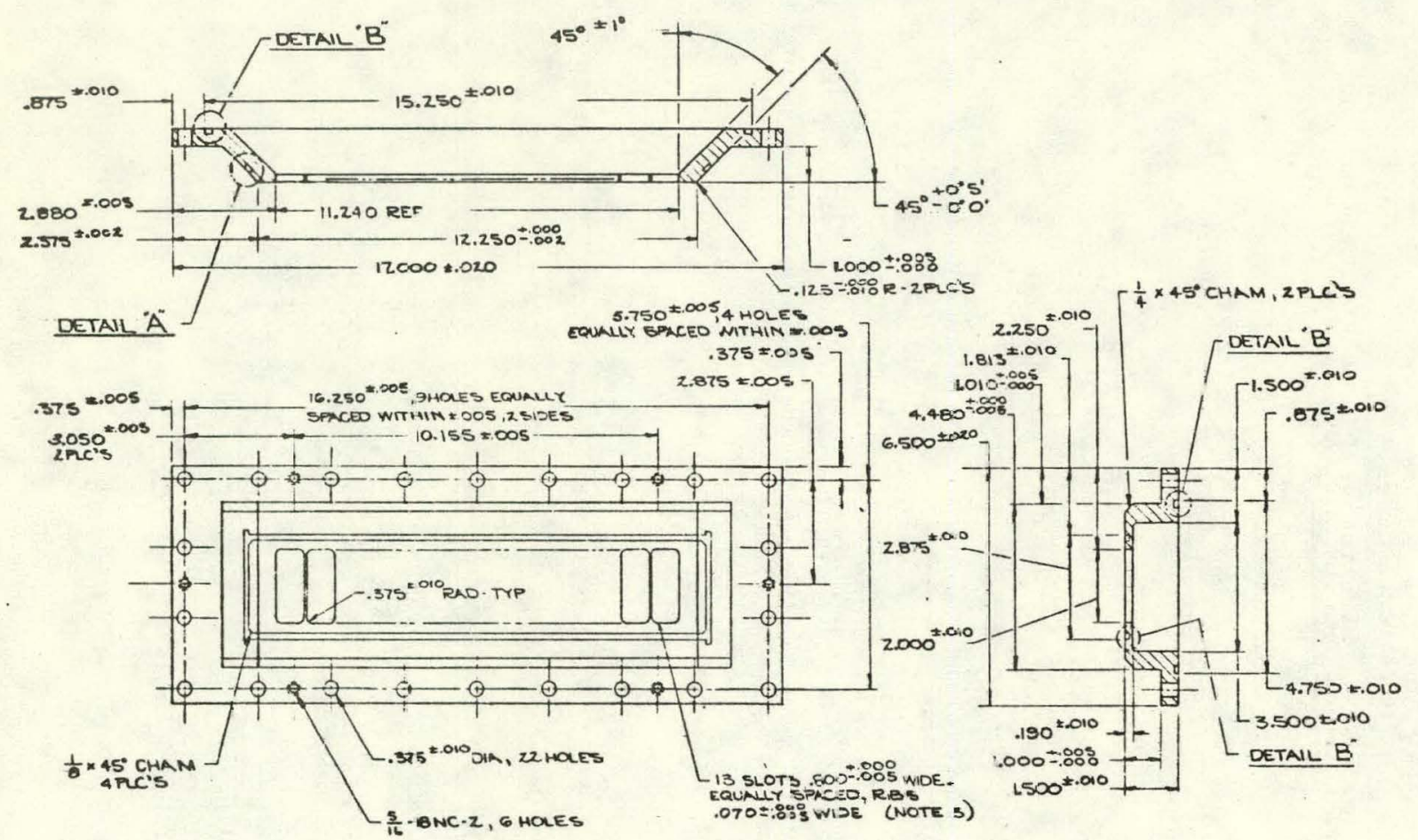

\section{NOTES}

1. GENERAL MANUFACTURING INFORMATION 9800000 2. MATL, 303 STANLESS STEEL

3. BREAK ALL EOGES AROUND S-OTS DOS

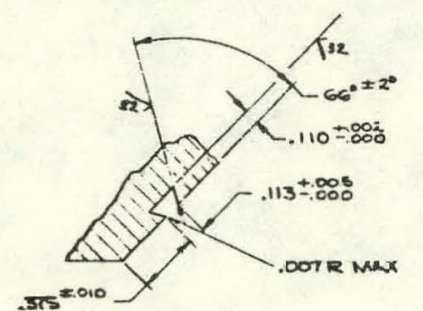

OETAI: 'A"

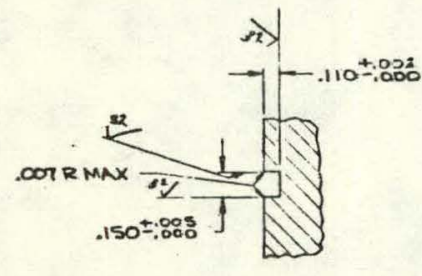

DETAIL' $B$ '

\section{ITEM 5}

Dwg. 6. Laser Cavity Burst Diaphram Holler (FPS) 


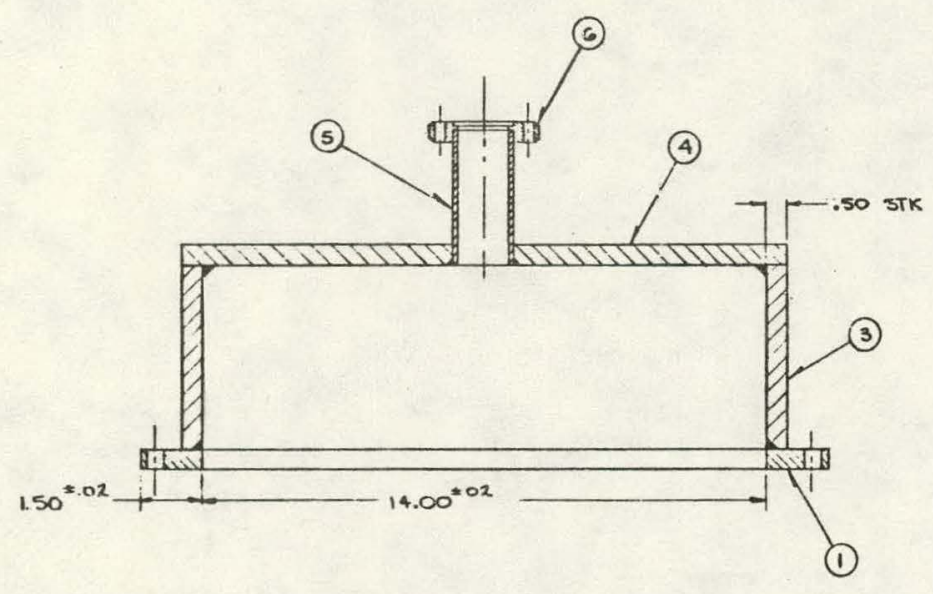

NOTES

L GENERAL MANUFACT

2. WEL NNO INSPECT PER 991Z119.CLASS 11 LSING DECTRODE PER ASTM A29B. CLASS E 30 . IS OR BARE EIECTRODE PER MIL-E-19933, TIPE MIL- 308 3. THIS ASSEMBLY SHALL MAVE NO DETECTABLE LEAKS WHEN
TESTED WITHA MASS SPECTROMETER MFE LEMK DETECTOR AT SENSITIVITIES $10^{-5}$ TO $10^{-6}$ CC/SEC STP

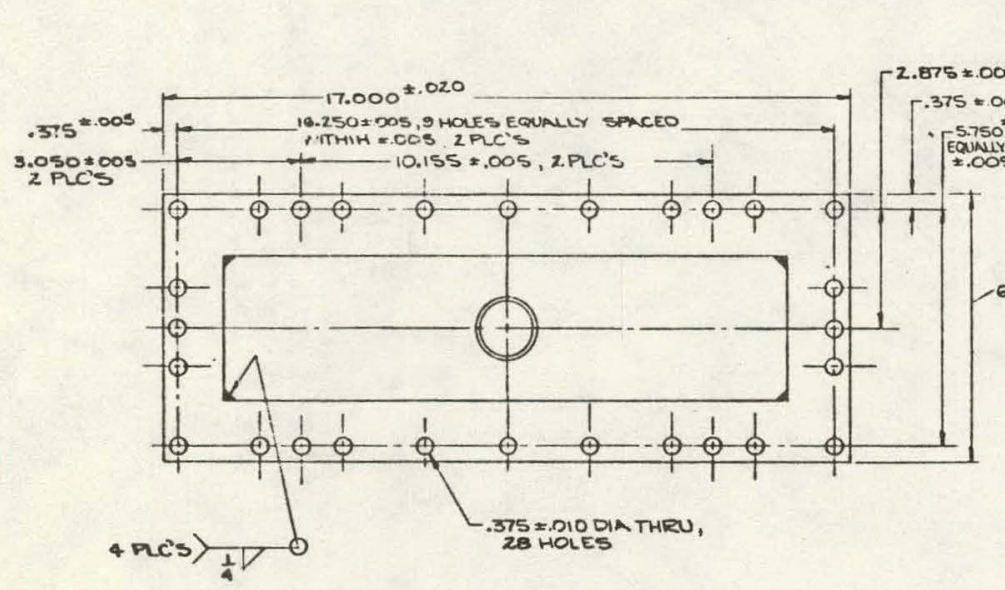

ITEM 6

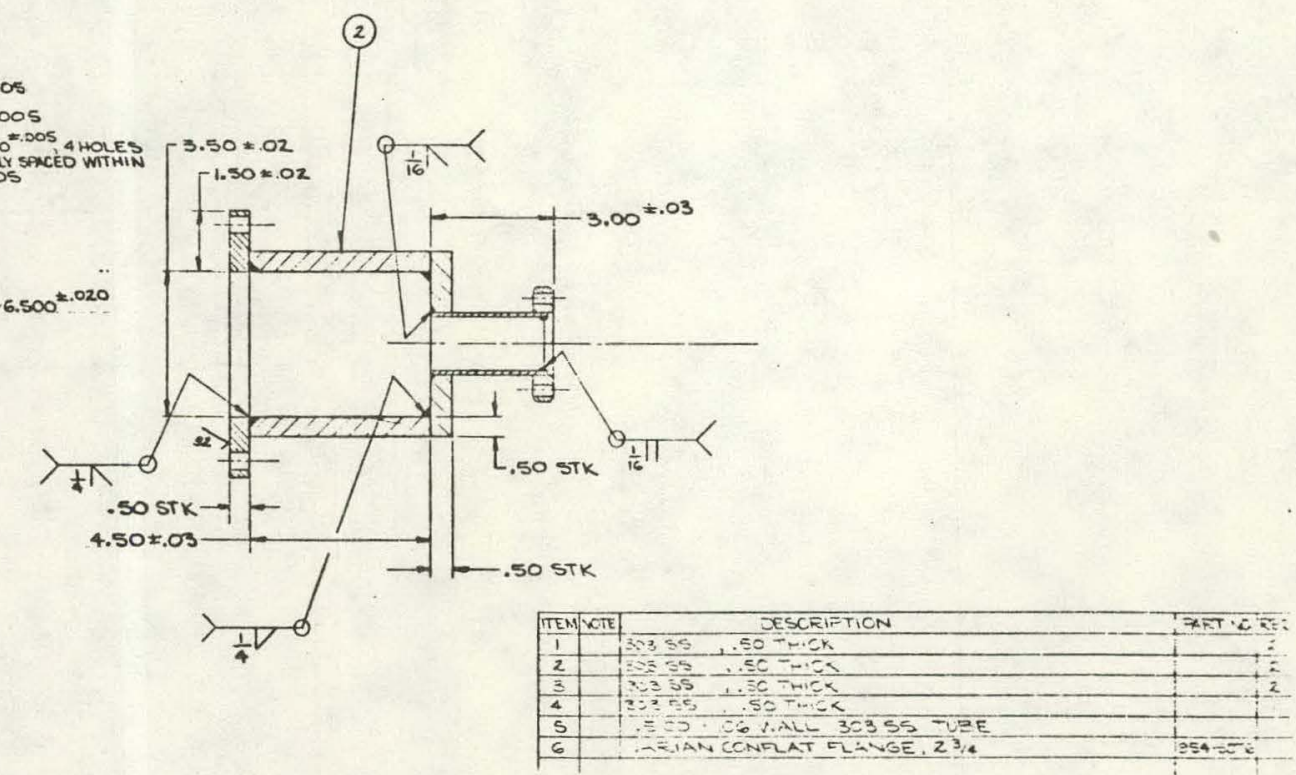



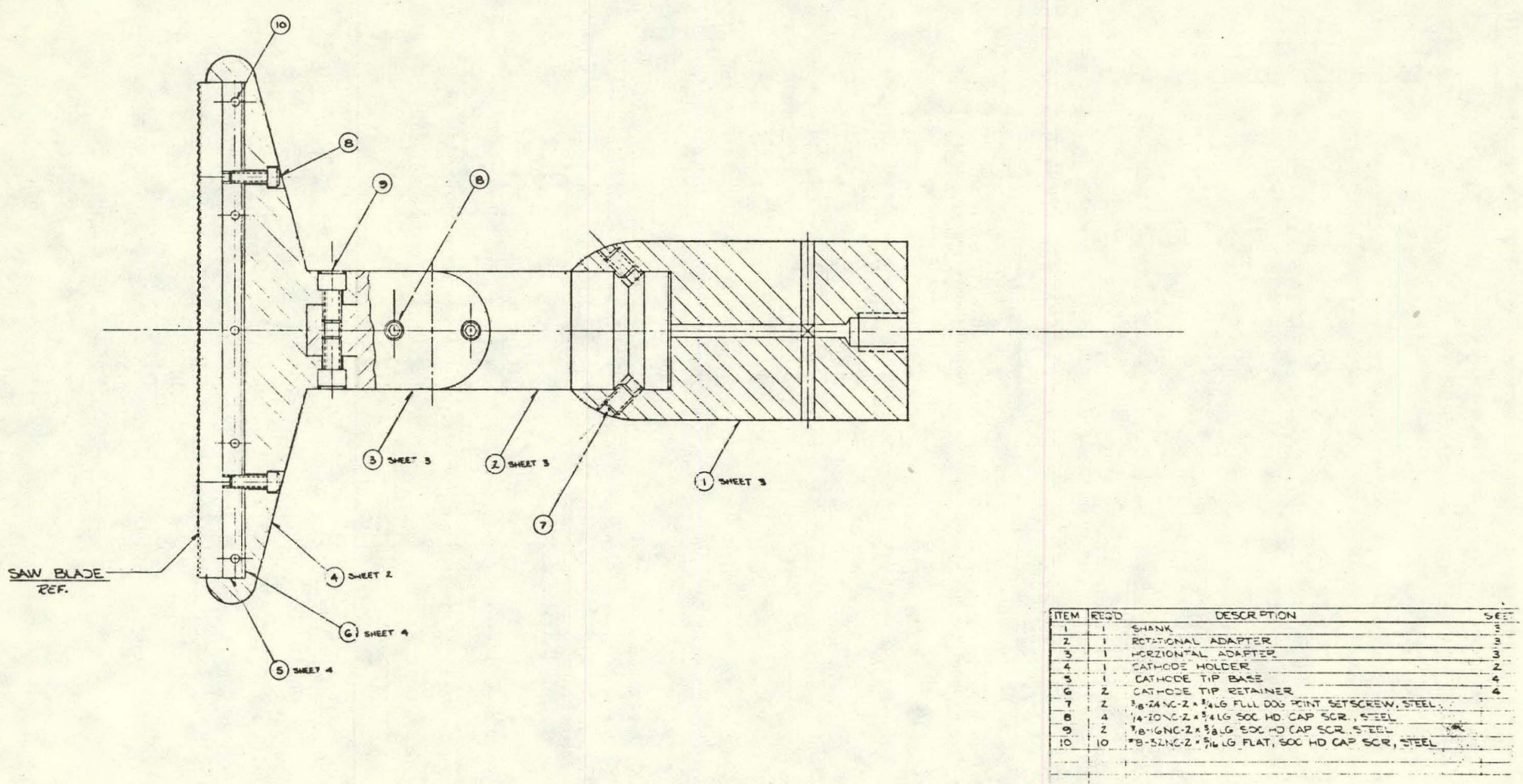

Dwg. 8. Cathode Assembly (PPS) 


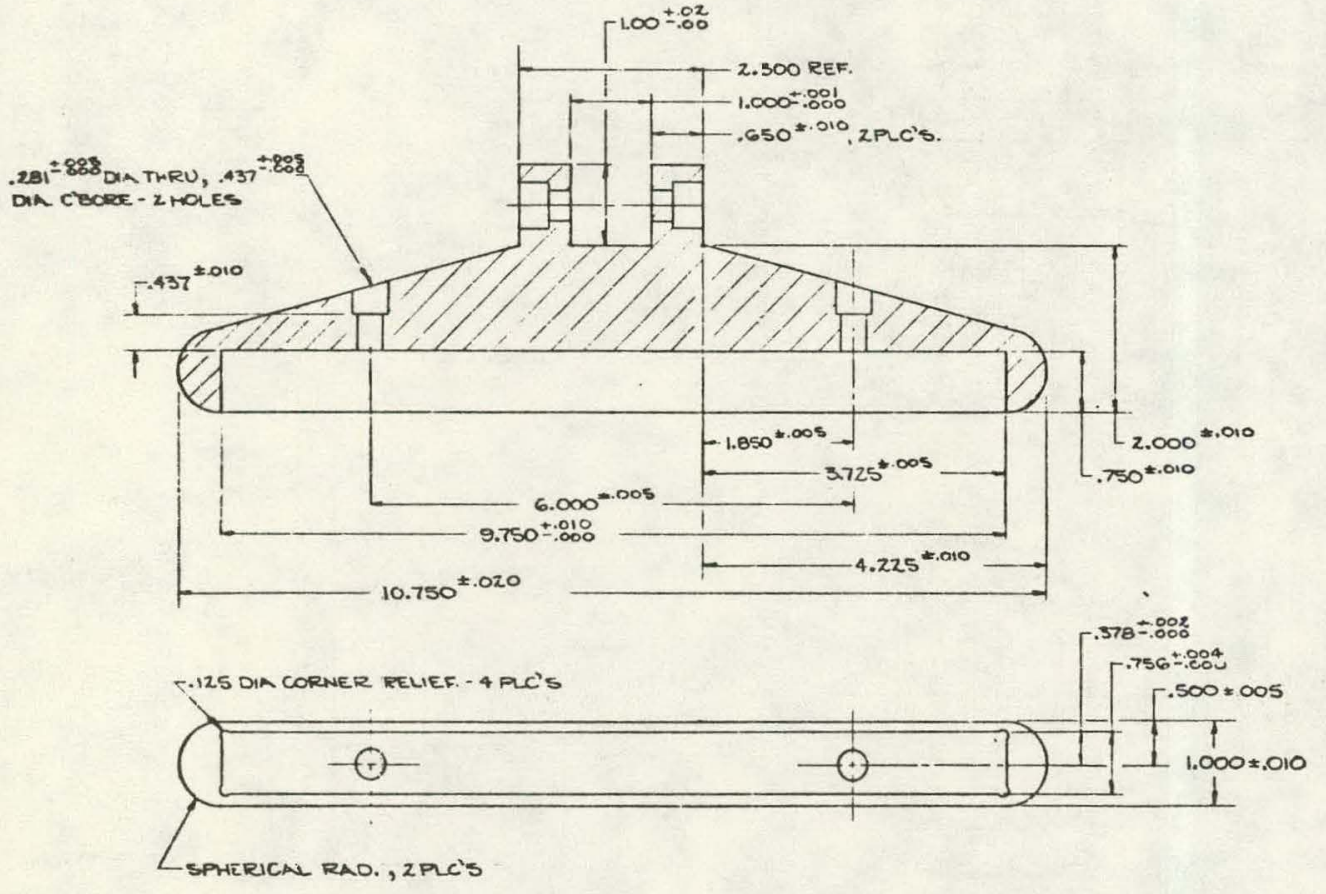

ITEM 4

\section{NOTES}

1. GENERAL MANUFACTURING INFORMATION 9900000 2. MATL GOGI-TG NLUM

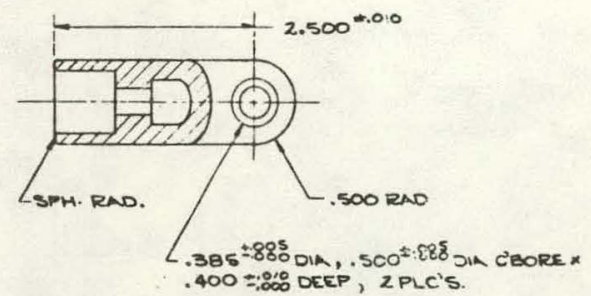



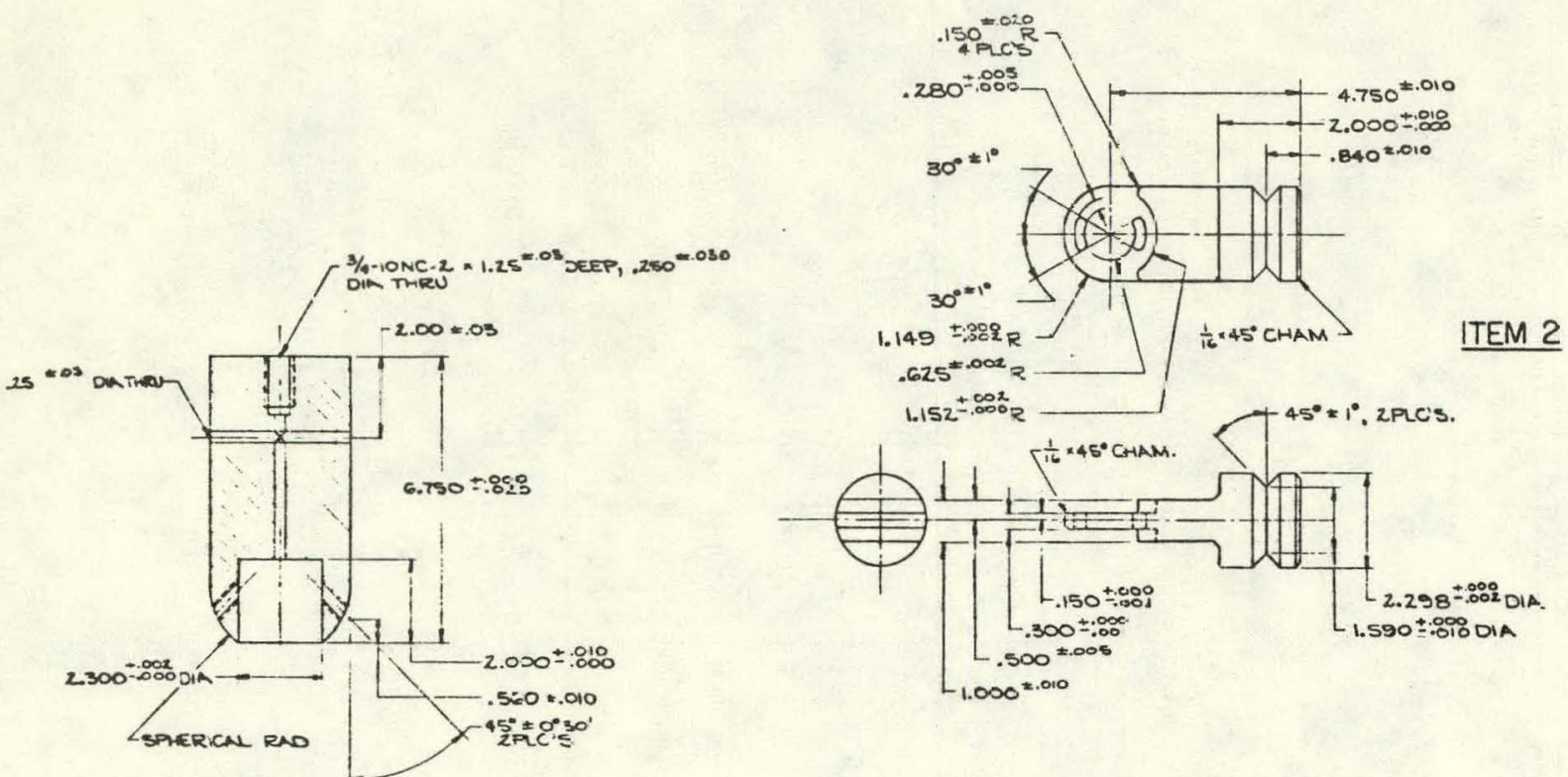

NOTES

7. GENERAL MANUFACTURING INFCRMMTTON 9900000

2. MATL: SOS STMNLESS STL.

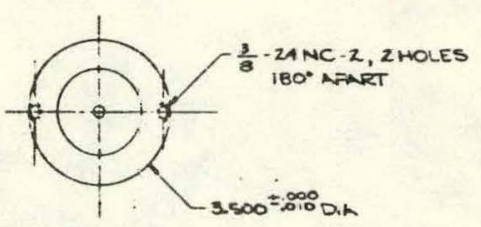

ITEM

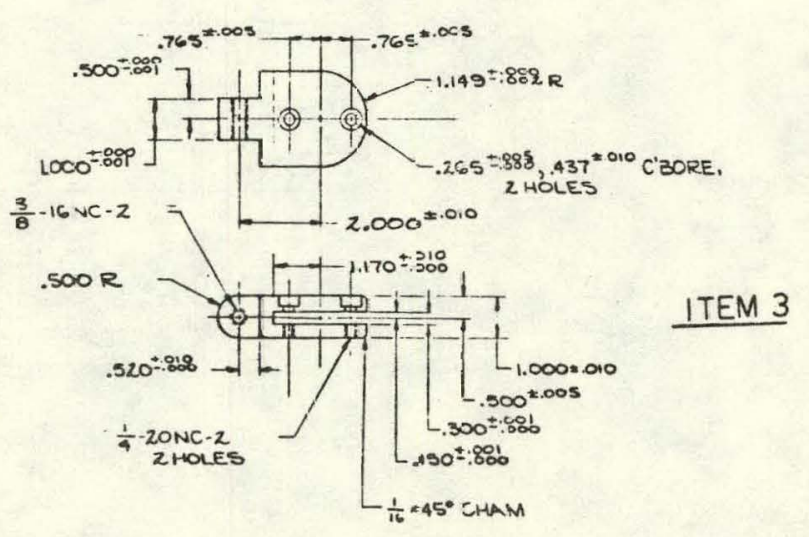

Dwg. 10. Ca.thode (PPS) 


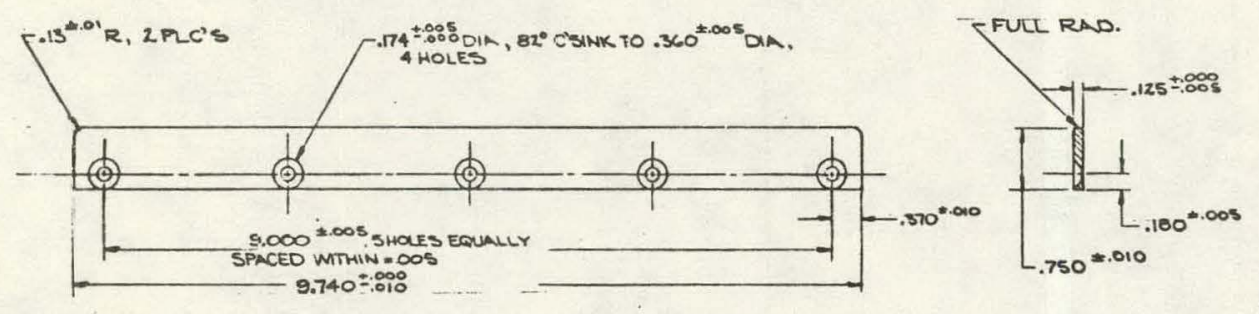

\section{ITEM 6}

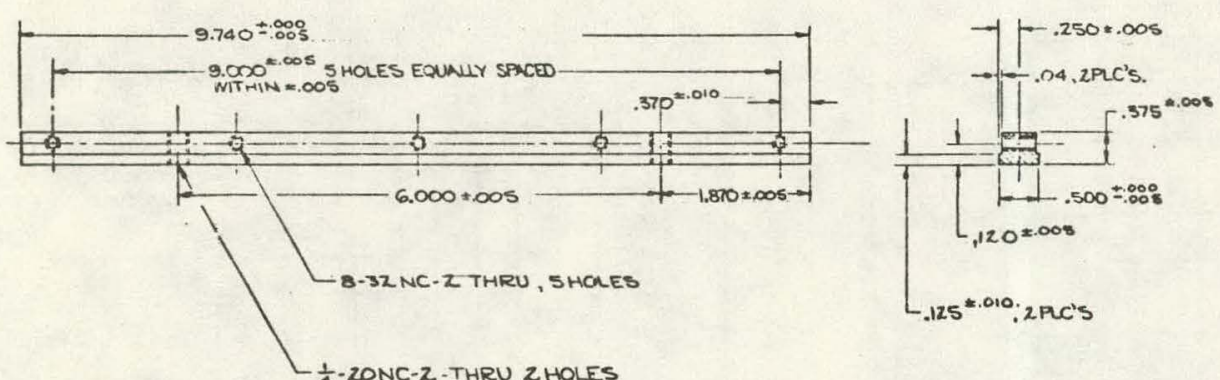

ITEM 5 


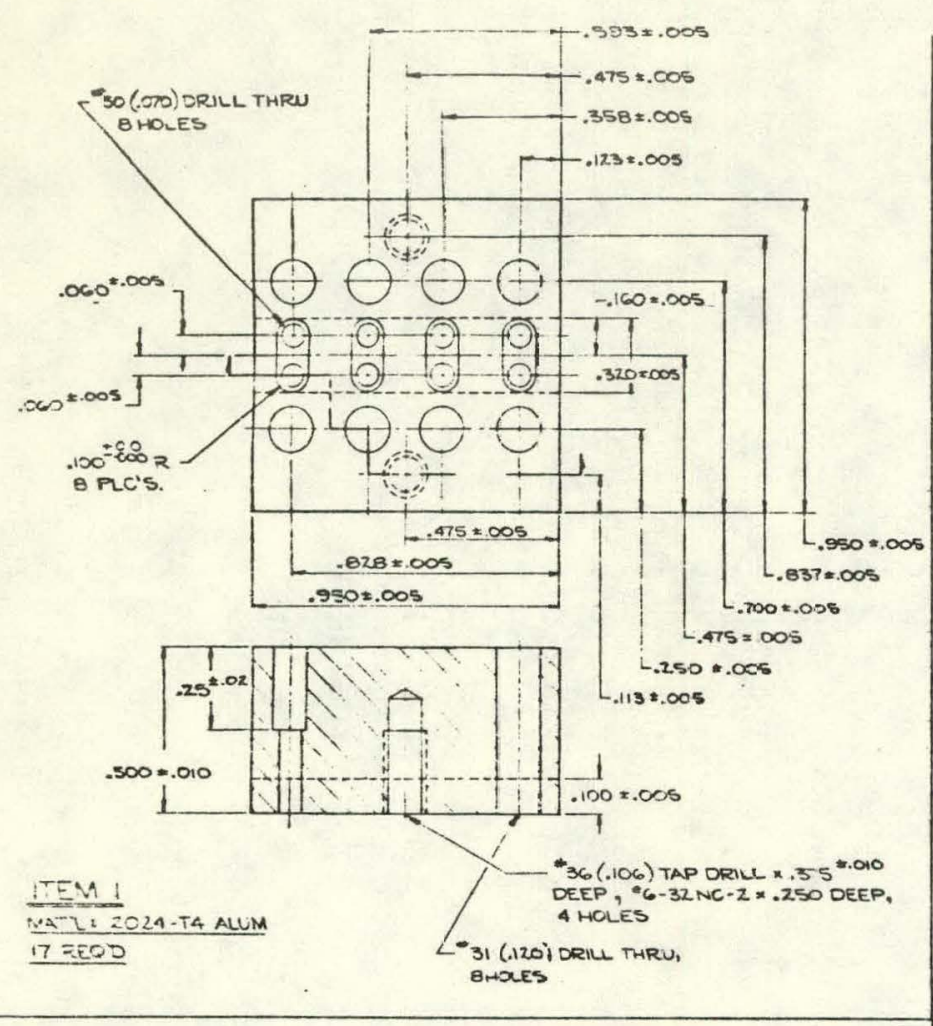

4 - 20 HOC-Z TAP THZU
2 MOLS

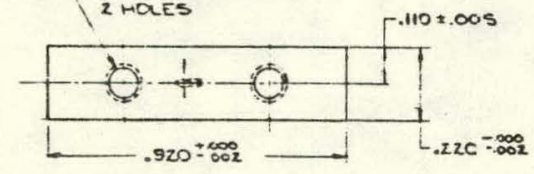

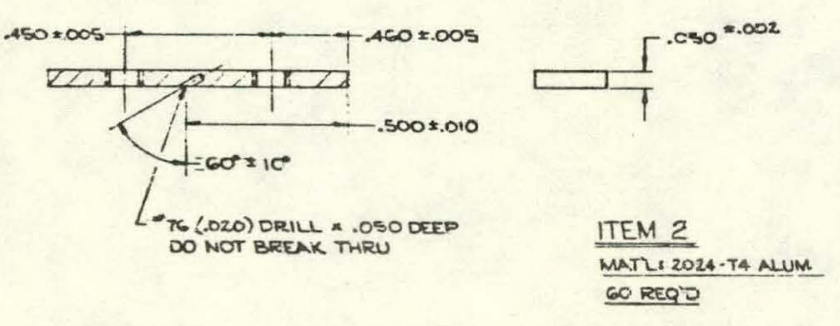

Dwg. 12. Calorimeter (PבS)
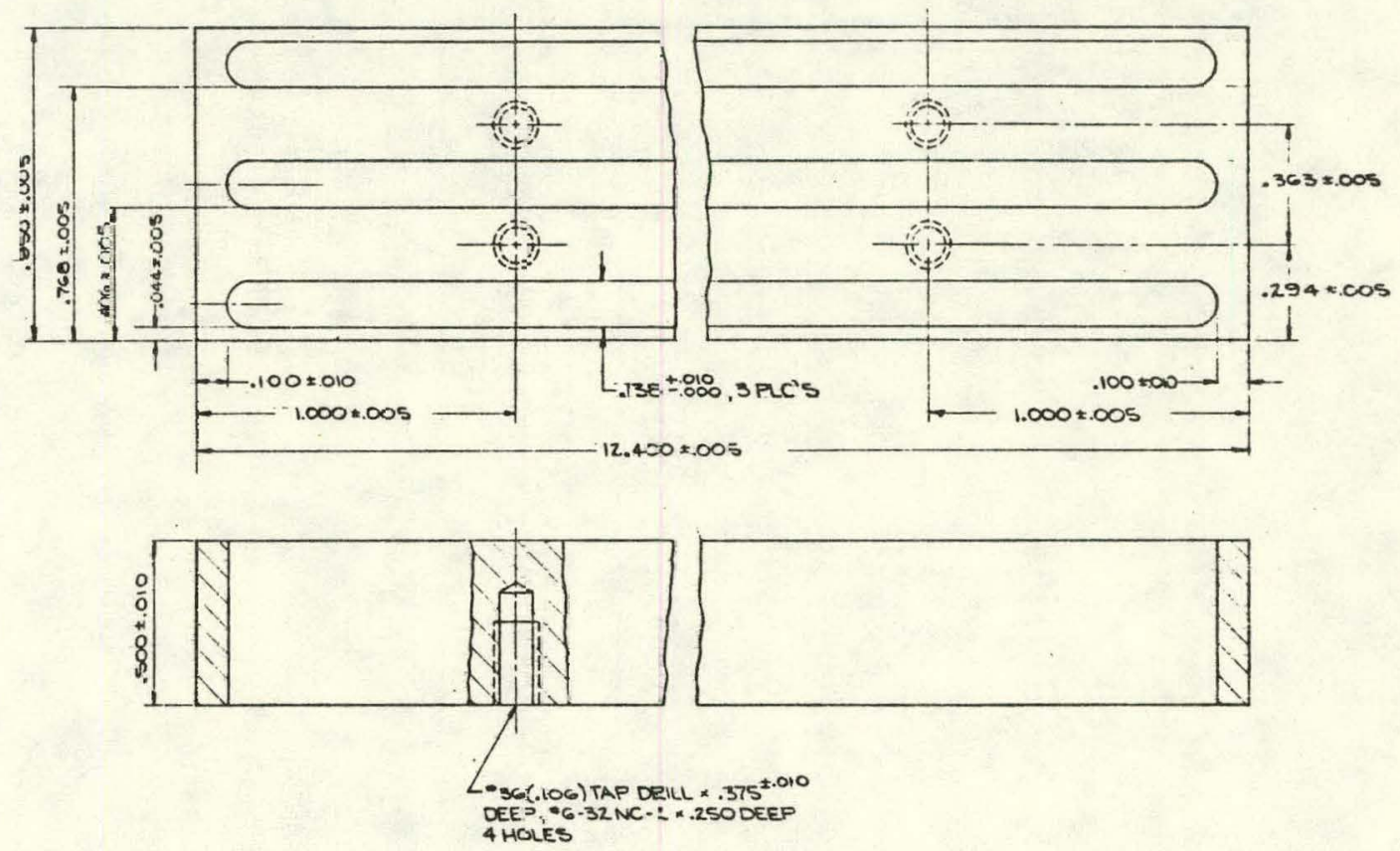

ITEM 3

MAT L: 2OZ4-TA ALUM IREQ'D. 


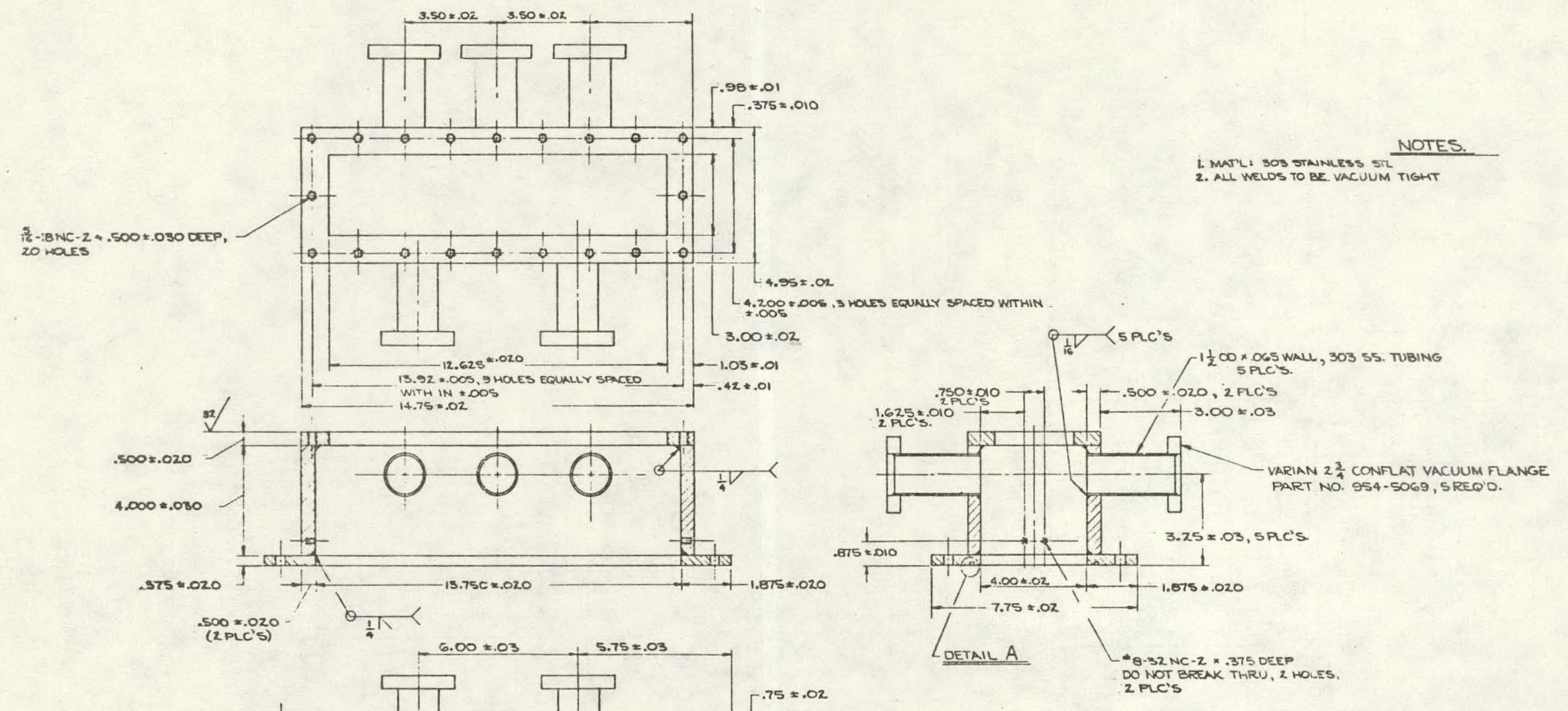



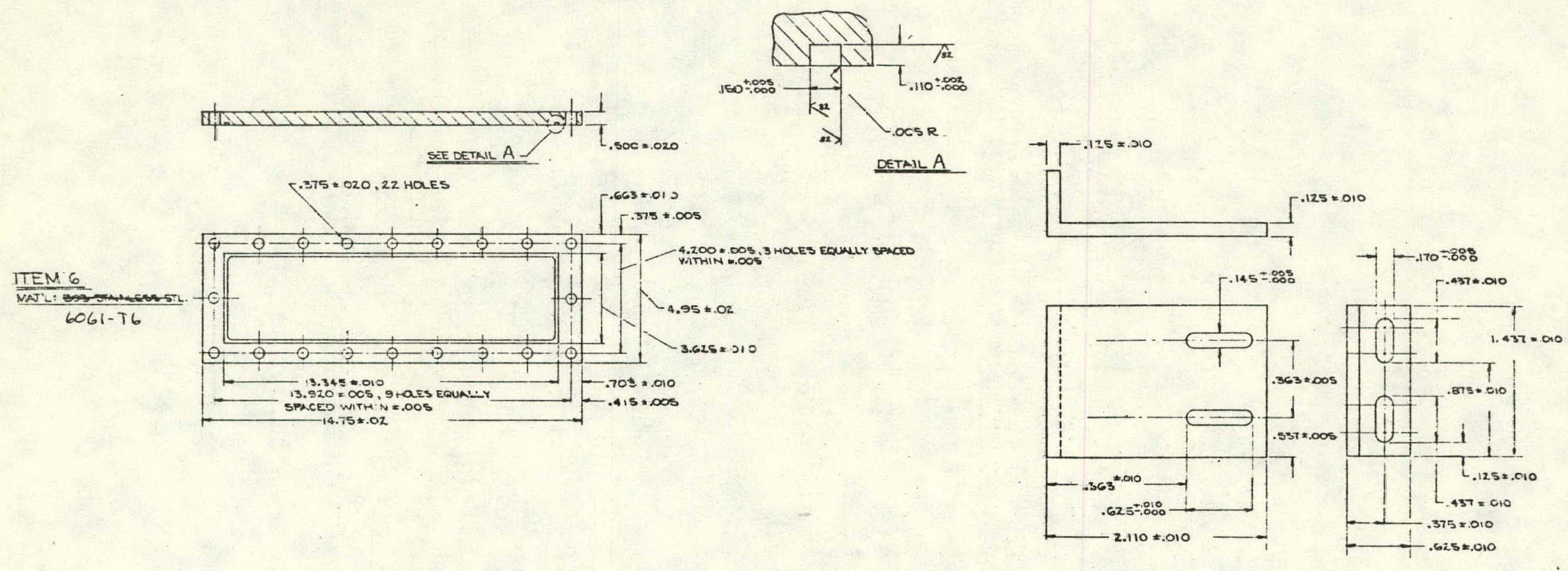

ITEM 5

MATL: 303 STAN_ESS STL. 

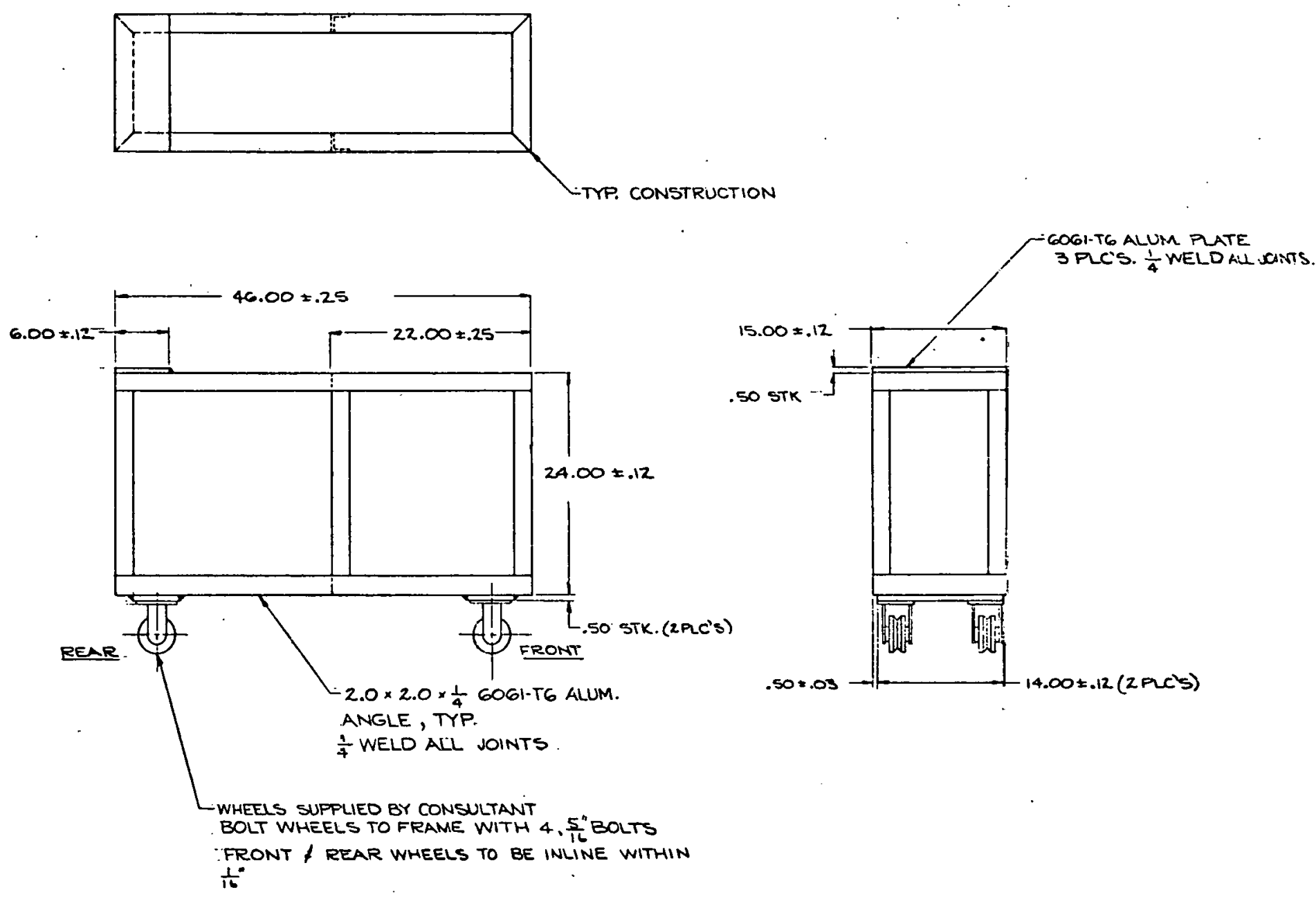
UNLIMITED RELEASE

Distribution:

US DOE/NS

Washington, DC 20545

Attn: G. W. Gibbs

University of California

Lawrence Livermore National Laboratory

P. 0. Box 808

Livermore, CA 94550

Attn: L. D. Pleasance

E. V. George

Los Alamos Scientific Tahoratory

P. 0. Box 1663

Los Alamos, NM 87544

Attn: C. Fenslerwacher

W. J. Schafer Associates, Inc.

1901 North Ft. Myer Drive

Suite 803

Arlington, VA 22209

Attn: E. Gerry

TRW

1 Space Park

Redondo Beach, CA 90278

Attn: R. Aprahamian

AVCO Everett Research, Inc.

Fiverett, MA 02149

Attn: J. Daugherty

U. S. Air Force

Air Force Weapons Laboratory

Kirtland AFB, NM 87117

Attn: P. J. Ortwerth, AI.C

Maj. S. R. Czyzak

U. S. Naval Research Laboratory

Washington, DC 20390

Attn: S. K. Searlco

Maxwell Labs

9244 Balboa Avenue

San Diego, CA 92123

Attnt A. Kolb
Physics International

2700 Merced Street

San Leandro, CA 94577

Attn: J. Martinez

Osaka University

Institute of Laser Engineering

Osaka 565, Japan

Atțn: C. Yamanaka

Keio University

Department. of Electrical

Engineering

3-14-1 Hiyoshi, Kohoku-Ku

Ynkonhama 223, Japan

Attn: Tomoo Fujioka

Minoru Obara

4000

4200

A. Narath

4210

G. Yonas

4211 .

4212

J. B. Gerardo

E. J. McGuire

4212

4212

R. A. Gerber (5)

C. A. Frost

R. A. Hami 1

4212

4212

J. M. Hof fman

4212

R. A. Klein (20)

4212

4212

J. B. Moreno

E. L. Pacterson

4212

4212

4212

4214

4216

4218

4220

4230

G. E. SamLIn

J. H. Stoever

G. C. Tisone

J. R. Woodworth

$E$. D. Jones

A. W. Johnson

J. K. Rice

M. Cowan

J. E. Powe11

4240

4250

G. W. Kuswa

4253

I. Il. Martili

4253

K. R. Prestwich

8266

3141

J. J. Ramirez

E. A. Aas

L. J. Erickson (5)

3131

W. L. Garner (3)

(for DOE/TIC)

3154-3 R. P. Campbe11 (25) 


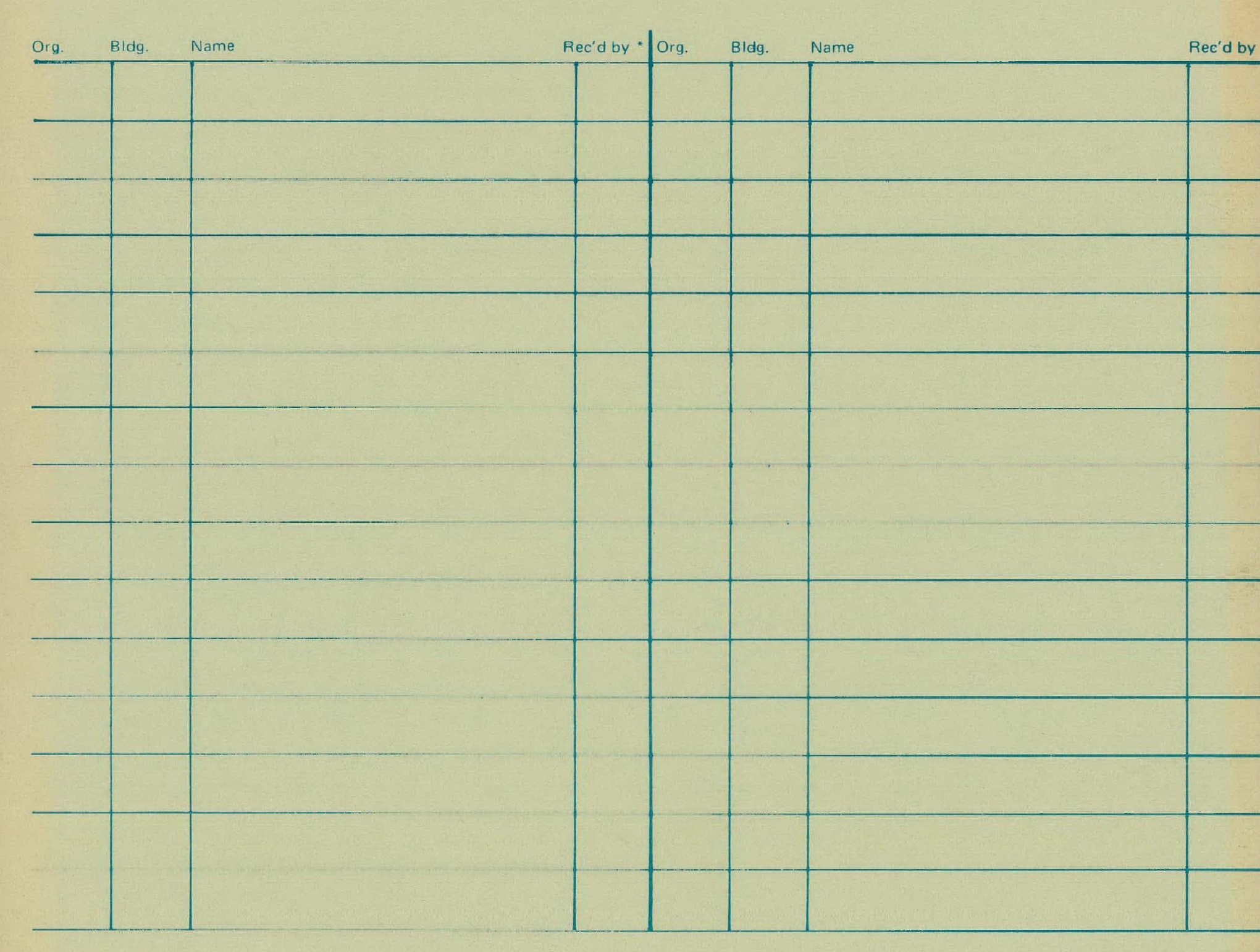

